\title{
Rare ground data confirm significant warming and drying in western equatorial Africa
}

\author{
Emma R Bush ${ }^{\text {Corresp., } 1}$, Kathryn Jeffery ${ }^{1,2}$, Nils Bunnefeld ${ }^{1}$, Caroline Tutin $^{1}$, Ruth Musgrave ${ }^{3}$, Ghislain Moussavou ${ }^{4}$, \\ Vianet Mihindou $^{2,5}$, Yadvinder Malhi ${ }^{6}$, David Lehmann ${ }^{1,2}$, Josué Edzang Ndong ${ }^{2}$, Loïc Makaga ${ }^{2}$, Katharine A \\ Abernethy ${ }^{1,7}$ \\ ${ }^{1}$ Faculty of Natural Sciences, University of Stirling, Stirling, United Kingdom \\ 2 Agence Nationale des Parcs Nationaux (ANPN), Libreville, Gabon \\ 3 Elephant Protection Initiative, London, UK \\ 4 Agence Gabonaise d'études et d'Observation Spatiale (AGEOS), Libreville, Gabon \\ 5 Ministère des Eaux et Forêts, charge de l'Environnement et du Développement Durable, Libreville, Gabon \\ 6 Environmental Change Institute, School of Geography and the Environment, University of Oxford, Oxford, United Kingdom \\ 7 Institut de Recherche en Écologie Tropicale, CENAREST, Libreville, Gabon \\ Corresponding Author: Emma R Bush \\ Email address: e.r.bush@stir.ac.uk
}

Background. The humid tropical forests of Central Africa influence weather worldwide and play a major role in the global carbon cycle. However, they are also an ecological anomaly, with evergreen forests dominating the western equatorial region despite less than $2000 \mathrm{~mm}$ total annual rainfall. Meteorological data for Central Africa are notoriously sparse and incomplete and there are substantial issues with satellite-derived data because of persistent cloudiness and inability to ground-truth estimates. Long-term climate observations are urgently needed to verify regional climate and vegetation models, shed light on the mechanisms that drive climatic variability and assess the viability of evergreen forests under future climate scenarios.

Methods. We have the rare opportunity to analyse a 34-year dataset of rainfall and temperature (and shorter periods of absolute humidity, wind speed, solar radiation and aerosol optical depth) from Lopé National Park, a long-term ecological research site in Gabon, western equatorial Africa. We used (generalized) linear mixed models and spectral analyses to assess seasonal and inter-annual variation, long-term trends and oceanic influences on local weather patterns.

Results. Lopé's weather is characterised by a cool, light-deficient, long dry season. Long-term climatic means have changed significantly over the last 34 years, with warming occurring at a rate of $+0.25{ }^{\circ} \mathrm{C}$ per decade (minimum daily temperature) and drying at a rate of $-75 \mathrm{~mm}$ per decade (total annual rainfall). Inter-annual climatic variability at Lopé is highly influenced by global weather patterns. Sea surface temperatures of the Pacific and Atlantic oceans have strong coherence with Lopé temperature and rainfall on multi-annual scales.

Conclusions. The Lopé long-term weather record has not previously been made public and is of high value in such a data poor region. Our results support regional analyses of climatic seasonality, long-term warming and the influences of the oceans on temperature and rainfall variability. However, warming has occurred more rapidly than the regional products suggest and while there remains much uncertainty in the wider region, rainfall has declined over the last three decades at Lopé. The association between rainfall and the Atlantic cold tongue at Lopé lends some support for the "dry" models of climate change

Peer] reviewing PDF | (2019:05:37246:2:0:NEW 28 Jan 2020) 
for the region. In the context of a rapidly warming and drying climate, urgent research is needed into the sensitivity of dry season clouds to ocean temperatures and the viability of humid evergreen forests in this dry region should the clouds disappear. 


\section{Rare ground data confirm significant warming 2 and drying in western equatorial Africa}

3 Emma R Bush ${ }^{1}$, Kathryn J. Jeffery ${ }^{1,2}$, Nils Bunnefeld ${ }^{1}$, Caroline Tutin ${ }^{1}$, Ruth Musgrave ${ }^{3}$,

4 Ghislain Moussavou ${ }^{4}$, Vianet Mihindou ${ }^{2,5}$, Yadvinder Malhi ${ }^{6}$, David Lehmann ${ }^{2}$, Josué Edzang

5 Ndong $^{2}$, Loïc Makaga ${ }^{2}$, Katharine A. Abernethy ${ }^{1,7}$

6

$7 \quad 1$ Faculty of Natural Sciences, University of Stirling, Stirling, UK

82 Agence Nationale des Parcs Nationaux (ANPN), Libreville, Gabon

93 Elephant Protection Initiative, London, UK.

104 Agence Gabonaise d'études et d'Observation Spatiale (AGEOS), Libreville, Gabon

115 Ministère des Eaux et Forêts, charge de l'Environnement et du Développement Durable,

12 Libreville, Gabon

136 Environmental Change Institute, School of Geography and the Environment, University of

14 Oxford, UK

157 Institut de Recherche en Écologie Tropicale, CENAREST, Libreville, Gabon

18 Corresponding Author:

19 Emma R. Bush,

20 Faculty of Natural Sciences, University of Stirling, Stirling, FK9 4LA, UK

21 Email address: e.r.bush@stir.ac.uk 


\section{Abstract}

24 Background. The humid tropical forests of Central Africa influence weather worldwide and

25

26

27

28

29

30 play a major role in the global carbon cycle. However, they are also an ecological anomaly, with evergreen forests dominating the western equatorial region despite less than $2000 \mathrm{~mm}$ total annual rainfall. Meteorological data for Central Africa are notoriously sparse and incomplete and there are substantial issues with satellite-derived data because of persistent cloudiness and inability to ground-truth estimates. Long-term climate observations are urgently needed to verify regional climate and vegetation models, shed light on the mechanisms that drive climatic variability and assess the viability of evergreen forests under future climate scenarios.

Methods. We have the rare opportunity to analyse a 34-year dataset of rainfall and temperature (and shorter periods of absolute humidity, wind speed, solar radiation and aerosol optical depth) from Lopé National Park, a long-term ecological research site in Gabon, western equatorial Africa. We used (generalized) linear mixed models and spectral analyses to assess seasonal and inter-annual variation, long-term trends and oceanic influences on local weather patterns. Results. Lopé's weather is characterised by a cool, light-deficient, long dry season. Long-term climatic means have changed significantly over the last 34 years, with warming occurring at a rate of $+0.25^{\circ} \mathrm{C}$ per decade (minimum daily temperature) and drying at a rate of $-75 \mathrm{~mm}$ per decade (total annual rainfall). Inter-annual climatic variability at Lopé is highly influenced by global weather patterns. Sea surface temperatures of the Pacific and Atlantic oceans have strong coherence with Lopé temperature and rainfall on multi-annual scales.

Conclusions. The Lopé long-term weather record has not previously been made public and is of high value in such a data poor region. Our results support regional analyses of climatic seasonality, long-term warming and the influences of the oceans on temperature and rainfall variability. However, warming has occurred more rapidly than the regional products suggest and while there remains much uncertainty in the wider region, rainfall has declined over the last three decades at Lopé. The association between rainfall and the Atlantic cold tongue at Lopé lends some support for the "dry" models of climate change for the region. In the context of a rapidly warming and drying climate, urgent research is needed into the sensitivity of dry season clouds to ocean temperatures and the viability of humid evergreen forests in this dry region should the clouds disappear. 


\section{Abstract (French)}

55 Introduction: Les forêts tropicales d'Afrique Centrale ont une influence sur le climat mondial et joue un rôle majeur dans le cycle global du carbone. Pourtant, ces sont des anomalies écologiques puisque ces forêts vertes dominent la région équatoriale de l'ouest malgré des pluies annuelle de moins de $2000 \mathrm{~mm}$. Les données météorologiques d'Afrique Centrale sont connues pour être temporellement et géographiquement incomplètes. Les données climatiques de surface dérivées des données satellites sont souvent inexploitables au vu du couvert nuageux. Les observations climatiques sur le long terme sont donc urgemment nécessaires afin de confronter les différents modèles évolutifs du climat et de la végétation mettant en lumières les mécanismes de variation climatiques et de la survie de ces forêts dans un contexte de réchauffement 64 climatique.

Méthodes: Nous avons eu l'opportunité rare d'analyser 34 années de données de précipitation et de température collectées dans le Parc National de La Lopé au centre du Gabon (et des périodes plus courtes d'humidité absolue, de vitesse du vent, de radiation solaire et de profondeur optique des aérosols dans l'atmosphère). Nous avons utilisé des modèles (généralisés) linéaire mixes et des analyses spectrales afin d'observer les variation saisonnières et interannuelles, les tendance climatiques sur le long-terme ainsi que l'influence de l'océan sur le comportement du climat local.

Résultats: Le climat de La Lopé est caractérisé par une longue saison sèche, froide à faible luminosité. Les moyennes climatiques ont changé de manière significative durant les trois dernières décennies, avec un réchauffement observé de $+0.25^{\circ} \mathrm{C}$ par décennie (température minimale journalière) and un taux d'assèchement de $-75 \mathrm{~mm}$ par décennie (précipitation annuelle totale). La variabilité interannuelle à Lopé est fortement influencée par les conditions météorologiques. Les températures de la surface de les océans Pacifique et Atlantique sont fortement cohérentes avec la température de la Lopé et les précipitations sur une échelle de temps multi-annuelle.

Conclusions: Le relevé météorologique à long terme de la Lopé n'a pas été rendu public auparavant et est d'une grande valeur dans une région pauvre en données. Nos résultats appuient les analyses régionales de la saisonnalité climatique, du réchauffement à long terme et des influences des océans sur la variabilité des températures et des précipitations. Cependant, le réchauffement s'est produit plus rapidement que ne le suggèrent les produits régionaux et bien qu'il reste beaucoup d'incertitude dans la région élargie, les précipitations ont diminué au cours des trois dernières décennies à Lopé. Les données de la Lopé supportent l'hypothèse de « la langue froide » dans les modèles sec de changement climatique pour la région. Dans un contexte de réchauffement et d'assèchement rapide du climat, des recherches additionnelles portant sur la variabilité du couvert nuageux en fonction des températures océaniques sont urgemment nécessaires afin de prédire la survie des forets vertes dans cette région sèche si les nuages venaient à disparaitre. 


\section{Introduction}

94 The humid forests of Central Africa make up 30\% of the world's tropical forests (Malhi et al. 2013), are a major carbon store (Lewis et al. 2013) and influence weather globally (Bonan 2008; Washington et al. 2013). Most African evergreen tropical forests are found in the western equatorial region where total annual rainfall is less than $2000 \mathrm{~mm}$ rainfall (Philippon et al. 2019). Evergreen forests can be maintained in this relatively dry region due to reduced water demand during seasonal drought associated with extreme cloudiness (Philippon et al. 2019). Long-term changes to climate and climatic variability in the region (James et al. 2013) are likely to have farreaching impacts on the functioning of these evergreen tropical forests (Asefi-najafabady \& Saatchi 2013; Zhou et al. 2014) with knock-on effects for the global carbon cycle (Mitchard 2018) and local human livelihoods (Niang et al., 2014). However, evidence for changes in forest function linked to weather conditions in equatorial Africa is extremely rare, mainly due to missing long-term meteorological data. The number of rain gauge stations reporting data across Central Africa fell from a peak of more than 50 between 1950 and 1980 to fewer than ten in 2010 (Washington et al. 2013). This low density of observations and poor understanding of local landscape and climatic processes (Nicholson \& Grist 2003) limits the accuracy of gridded observational data products (Asefi-najafabady \& Saatchi 2013; Suggitt et al. 2017). Uncertainty is particularly high for rainfall patterns, which unlike temperature, are poorly conserved over space (Habib et al. 2001; Kidd et al. 2017). Because of missing ground data, climate and ecological models rely heavily on satellites despite major issues with this data source that include extreme cloudiness in the region and little

114 opportunity for ground-truthing (Washington et al. 2013; Maidment et al. 2014; Wilson \& Jetz

115 2016; Dommo et al. 2018). Empirical meteorological data are urgently needed to verify regional

116 climate and vegetation models and shed light on the mechanisms that drive seasonal and long-

117 term climatic variability in tropical Africa (Guan et al. 2013; Abernethy et al. 2016).

118 We have the rare opportunity to analyse a 34-year record of rainfall and temperature (and shorter periods of humidity, wind speed, solar radiation and aerosol optical depth) from a long-term ecological research site in western equatorial Africa. These local weather data have not contributed to the available climate products (such as the high-resolution gridded dataset from the Climate Research Unit) and are able to act as an independent control. In this paper we briefly review the published literature on drivers of weather variability and long-term climate trends in western equatorial Africa $\left(\sim 6^{\circ} \mathrm{S}-5^{\circ} \mathrm{N}, 8^{\circ}-18^{\circ} \mathrm{E}\right.$, covering Cameroon, Republic of Congo, Central African Republic, Democratic Republic of Congo, Equatorial Guinea and Gabon). We then use our ground data to analyse seasonal, inter-annual and long-term weather patterns in this data-

\section{Seasonality}

129 The climate of equatorial Africa is characterised by a bimodal rainfall pattern. Two rainy seasons 130 occur each year coinciding with the boreal spring and autumn when the sun passes directly over 131 the equator (March-May and October-November). Just 3\% total annual rainfall falls during the 
132 major dry season, which extends from June to August/September (Balas et al. 2007). The

133 primary influence on equatorial rainfall has historically been understood to be the Inter Tropical

134 Convergence Zone (ITCZ), a band of clouds and high precipitation that migrates northwards and

135 southwards over the equator following the sun (Nicholson 2018 and Fig. 1). However recent

136 developments show the ITCZ to be a poor explanation of seasonal rainfall in Africa, with ITCZ-

137 associated low-level convergence often decoupled from the rain belt in western and central

138 equatorial regions (Nicholson 2018). Improved mechanistic models of the seasonal evolution of

139 atmospheric conditions in the region are urgently needed.

140 In western equatorial Africa the rainy seasons coincide with bright conditions. Convection

141 clouds develop into storms late in the day or night leaving clear skies during the daytime (Gond

142 et al. 2013). By contrast, light is least available during the long dry season due to persistent low-

143 lying cloud cover throughout the day (Philippon et al. 2019). The seasonal synchrony between

144 light and precipitation in western equatorial Africa is in contrast to the central Congo Basin and

145 the neotropics where dry seasons tend to coincide with peak irradiance (Wright \& Calderón

146 2018; Philippon et al. 2019). In western equatorial Africa the long dry season is also the coolest

147 time of year (Munzimi et al. 2015; Tutin \& Fernandez 1993).

\section{Oceanic influences}

149 Large-scale patterns in sea surface temperatures (SSTs) are known to influence weather

150 conditions across the tropics (Camberlin et al. 2001; Fig. 1). The El Niño Southern Oscillation

151 (ENSO) refers to the state of the atmosphere and surface temperatures of the tropical Pacific

152 Ocean. ENSO has a relatively straightforward, instantaneous effect on temperature throughout

153 the African continent, with greater warming in El Niño years (Collins 2011). Central African

154 rainfall is also strongly connected to SSTs (Otto et al. 2013), although interactions are complex

155 and seasonally specific. In Table 1 we summarise six major studies of ocean influences on

156 rainfall in western equatorial Africa (Todd \& Washington 2004; Balas et al. 2007; Otto et al.

157 2013; Preethi et al. 2015 ; Nicholson \& Dezfuli 2013; Dezfuli \& Nicholson 2013). The main

158 agreements between these studies are that (1) rainfall is below average from February to August

159 in El Niño years (Camberlin et al. 2001; Todd \& Washington 2004; Balas et al. 2007; Preethi et

160 al. 2015; Nicholson \& Dezfuli 2013), (2) rainfall positively correlates with the temperature of the

161 Indian Ocean in January and February (Balas et al. 2007; Preethi et al. 2015) and (3) warm SSTs

162 in the tropical south Atlantic enhance rainfall from April-September (Camberlin et al. 2001;

163 Balas et al. 2007; Otto et al. 2013; Nicholson \& Dezfuli 2013). We found no evidence in the

164 literature for the influence of large-scale climate oscillations on other weather variables such as

165 light availability, wind speeds or aerosols in the region.

\section{Long-term trends}

167 There is high confidence in the evidence for warming over African land regions (Niang et al.

168 2014). Satellite estimates for tropical Africa show an annual mean temperature increase of

$1690.15^{\circ} \mathrm{C}$ per decade from $1979-2010$ (Collins 2011). A recent multi-model ensemble shows that 
170 mean temperature for the whole continent is likely to continue to increase more than the global

171 average especially in the long dry season (James \& Washington 2013).

172 Tropical land areas globally have seen no overall change in precipitation over the last century,

173 with a recent increase in precipitation (2003-2013) reversing a drying trend from the 1970s to the

174 1990s (Hartmann et al. 2013). Rainfall patterns are poorly conserved spatially and conflicting

175 trends are detected within the western equatorial region of Africa. A regionalised long-term

176 dataset for Africa constructed from historical records and rain gauge observations shows a sharp

177 reduction in rainfall in the Cameroon region from the late 1960s until the present and a

178 contrasting wetting trend in the Congo / Gabon region from 1980s until the present (Nicholson et

179 al. 2018). However a higher resolution analysis of the same dataset shows that within central

180 Gabon there has been a drying trend from the 1970s until 2000 and that there is no data

181 originating from this area for the last two decades (Nicholson et al. 2018). Flow data for the river

182 Ogooué - the largest river in western equatorial Africa - indicates that runoff in the region

183 declined from the 1960s until 2010 and that the flood peak has moved from May to April (Mahe

184 et al. 2013). Land-cover change has been minimal in the watershed during this period

185 (Abernethy et al. 2016) and so it is likely that reduced rainfall has been the biggest influence on

186 flow reduction.

187 Predictions of future rainfall vary widely across the African continent with high uncertainty in

188 the direction of change centrally due to the sparse network of observations and poor

189 understanding of local climate forcing (James \& Washington 2013). Model projections mostly

190 show no change or a weak wet signal in the central Congo Basin, and a dry signal in the western

191 region in scenarios where warming is greater than $2^{\circ} \mathrm{C}$ (James et al. 2013). Models that support a

192 drying trend in western equatorial Africa show strong associations with Atlantic and Indian (but

193 not Pacific) SSTs. The construction of these dry models suggests that reductions in rainfall in

194 Gabon and surrounding countries are likely to be caused by a northward displacement of the

195 equatorial rain belt associated with the Atlantic cold tongue (Fig. 1B) and an eastward shift in

196 convection caused by contrasts between Indian and Atlantic SSTs (James et al. 2013).

197 As for surface solar radiation, once again the picture varies spatially within central Africa. In the

198 central Congo Basin (14E-30E) there has been a recent widespread decline in cloud optical

199 thickness and no change in aerosol optical thickness (MODIS, 2000 -2012) leading to an

200 increase in downward photosynthetically available radiation (CERES, 2003-2012; Zhou et al.

201 2014). For sunshine duration, there has been no change in the central region but a weak decline

202 (2-4 hours per decade) in western equatorial Africa from 1983-2015 (SARAH-2, Kothe et al.

203 2017). There is no published data on long-term changes in relative humidity or wind speed in the 204 region.

\section{Implications for the eco-region}

206 Humid evergreen forests currently dominate western equatorial Africa despite relatively low

207 precipitation compared to other closed canopy tropical forests (Reich 1995). As summarized by

208 James et al. (2013), intense rainfall seasonality alongside a drying and warming climate is likely 
209 to lead to water stress and could push these ecosystems towards more open, fire prone, dry forest

210 systems (as evidenced in this region over the last 3000 years; Brncic et al. 2006 and in West

211 Africa in recent decades: Fauset et al. 2012) or even savanna (Willis et al. 2013). While

212 elevated atmospheric carbon dioxide improves water use efficiency, the balance of gains for

213 tropical forests related to carbon fertilization versus losses related to further warming and drying

214 are poorly characterized in climate and vegetation models (Huntingford et al. 2013). Tropical

215 forest species turnover or loss related to climate change will have serious consequences for

216 people and animals dependent on forest resources in the region (Abernethy et al. 2016) while

217 loss of tree cover will impact carbon storage and even feedback onto climate (Mitchard 2018).

218 Despite the risks associated with these scenarios few meteorological data are available,

219 especially in recent decades, to understand if the climatic trends described above are witnessed

220 on the ground and how quickly they are progressing. Using ground data from Lopé National Park

221 (NP), Gabon, collected over a 34-year period we ask: How fast is the region warming? Is the

222 region drying and how quickly? And how do the oceans influence rainfall and temperature

223 variability? Answers to these questions will be important to predict the viability of evergreen

224 forest ecosystems under future climates.

\section{Materials \& Methods}

226 Description of the study area and weather data recorded since 1984

227 The Station d'Études des Gorilles et Chimpanzées (SEGC) research station is located at the

228 northern end of Lopé National Park, Gabon $(-0.2 \mathrm{~N}, 11.6 \mathrm{E})$. The station sits in a tropical forest-

229 savanna matrix, at an elevation of $280 \mathrm{~m}$ and within $10.5 \mathrm{~km}$ of the river Ogooué (the largest

230 river in Gabon and the country's main watershed). Ecological research activities including

231 weather, plant and animal observations have taken place continuously at SEGC from 1984 until

232 the present (>300 publications; 1984-2018).

233 Weather data have been recorded at Lopé using various types of equipment at two locations: a

234 savanna site (the research station; $11.605 \mathrm{E},-0.201 \mathrm{~N})$ and a forest site $(800 \mathrm{~m}$ from the research

235 station and approximately $10 \mathrm{~m}$ from the savanna/forest edge; $11.605 \mathrm{E},-0.206 \mathrm{~N}$; Table 2$)$. From

2361984 to the present, a manual rain gauge was placed at the savanna site $(50 \mathrm{~cm}$ above ground and

$237>5 \mathrm{~m}$ from any tree or building) and used to record total daily rainfall at 8am each morning. There

238 was a gap in data recording in 2013 and occasional missing days due to logistical constraints

239 (e.g. availability of personnel). Since 1984 daily maximum and minimum temperatures and

240 relative humidity were recorded using a manual thermometer and wet/dry bulb located at the

241 forest site (1.5m aboveground under closed canopy), which were checked whenever field teams

242 passed it or daily when logistics permitted. In 2002 all temperature recording at the forest site

243 was transferred to continuous automatic units (ONSET HOBO ${ }^{\circledR}$ Data Loggers

244 refhttps://www.onsetcomp.com/, these units also recorded relative humidity). At the same time

245 temperature recording using the HOBO units also began in the savanna. Due to technical failures

246 these units were replaced in 2006 with the original manual max/min thermometer in the forest

247 and a digital $\mathrm{max} / \mathrm{min}$ thermometer (Taylor 1441) in the savanna. These were in turn replaced by 
248

249

250

251

252

253

254

255

256

257

258

259

260

261

262

263

264

265

266

267

268

269

270

271

272

273

274

275

276

277

278

279

280

281

282

283

284

285

286

another type of automated unit (TinyTag Plus 2, Gemini Data Loggers

https://www.geminidataloggers.com/data-loggers/tinytag-plus-2, some of which record both temperature and relative humidity). TinyTags were deployed in the forest from 2007 and in the savanna from 2008 and used until the present (with a gap at the forest site from mid-2015 to mid2016 and intermittent recording throughout 2017 partly due to equipment malfunctions caused by termite infestation). Two weather stations were installed in the savanna (sited near the research station, on a rock $4 \mathrm{~m}$ from the ground) and collected data between 2012 and 2016. A Davis VantagePro2 (https:/www.davisinstruments.com/solution/vantage-pro2/) was installed in January 2012 and recorded rainfall, temperature, relative humidity, pressure, wind speed and direction, UV index and solar radiation every 30 minutes for two years until the equipment was struck by lightning in January 2014. A SKYE MINIMET weather station (https://www.skyeinstruments.com/minimet-automatic-weather-station/) was installed at the same location in 2013 and collected temperature, relative humidity, wind speed and direction and solar radiation (but not rainfall as the gauge was defective). The SKYE unit ran intermittently until 2016 when the equipment was also damaged by lightning: data records between January 2014 and November 2014 were also lost. Finally, a sun photometer was installed at the research station in April 2014 and used to record aerosol optical depth up to the present as part of the NASA Aerosol Robotic Network (Aeronet; https://aeronet.gsfc.nasa.gov/; Holben et al. 1998). Despite sustained effort, the remote and challenging environment at Lopé has led to a patchy weather data record. This situation has been exacerbated since the introduction of automated loggers, due to unreliable performance combined with difficulties and time delays in replacing or repairing malfunctioning equipment and respecting annual calibration schedules with manufacturers based in Europe or the USA. New equipment was often introduced out of necessity when previous equipment failed, precluding the opportunity of collecting simultaneous data for standardisation. Such problems have been experienced at many other field stations across Africa (Maidment et al. 2017) and homogenisation is necessary in most long-term instrumental climatic data sets (Peterson et al. 1998). It was therefore necessary to select and standardise the Lopé data to reduce systematic biases between recording equipment. We summarise the data selection steps we undertook below and provide further detail in the accompanying Supplemental Information (Article S1 and Code S1). All Lopé data can be downloaded from the University of Stirling's DataSTORRE (http://hdl.handle.net/11667/133).

\section{Data cleaning and preparation}

We constructed a long-term record of daily rainfall totals (1984-2018) by calibrating the two sources of data (manual rain gauge and Vantage Pro weather station) using a simple linear model on simultaneous records and taking the mean value for days with multiple observations (resulting in a dataset of 12,050 complete daily observations out of a possible 12419 over 34 years). Where possible we interpolated missing daily values using the ten-day running mean for the time series (resulting in a dataset of 12111 interpolated daily observations), however 11 months spread over three calendar years remained incomplete. We used these interpolated daily data to calculate total 
287 monthly and annual rainfall for the months and years with complete data (397 complete monthly

288 observations out of a possible 408 and 31 complete years out of a possible 34).

289 Temperature data were recorded using six different types of equipment across two sites

290 (recorded in the forest from 1984 to 2018 and in the savanna from 2002 to 2018). Where there

291 were multiple observations from overlapping data records we calculated mean daily maximum

292 and minimum values for each site and day in the time series, and used this dataset to demonstrate

293 temperature seasonality at each site (resulting in a dataset of 7058 daily observations out of a

294 possible 12419 over 34 years at the forest and 4878 daily observations out of a possible 5844

295 over 16 years at the savanna). To create continuous time series for periodicity analyses we

296 calculated mean monthly maximum and minimum daily temperatures for each month in the time

297 series with more than five observations (resulting in a dataset of 327 monthly observations out of

298 a possible 408 from the forest site and 166 monthly observations out of a possible 192 at the

299 savanna site). Minimum daily temperatures are recorded during the night and thus avoid errors

300 associated with direct solar radiation (which we found to vary between our equipment, Article

301 S1). Because of this we chose to use minimum daily temperatures to assess long-term trends and

302 inter-annual variation. We constructed a long-term daily record by calculating mean daily

303 minimum temperature using data from both sites combined ( 8217 daily observations out of a

304 possible 12419 over 34 years). We summarized these data to a monthly mean time series for

305 months with more than five observations (372 monthly observations out of a possible 408 over

30634 years).

307 Finally, we used the shorter (and/or patchier) periods of data available for relative humidity

308 (2002-2018), solar radiation (2012-2016), wind speed (2012-2016) and aerosol optical depth

309 (2014-2017) to assess seasonality and periodicity for these climate variables. We used night-time

310 relative humidity records $(6 \mathrm{pm}-6 \mathrm{am})$ to avoid errors associated with direct solar radiation and

311 converted to absolute humidity $\left(\mathrm{g} / \mathrm{m}^{3}\right)$ using simultaneous temperature records within the $\mathrm{R}$

312 package humidity (Cai 2008). We extracted aerosol optical depth data at wavelengths relevant for

313 photosynthetic activity (440, 500 and $675 \mathrm{~nm})$.

\section{Gridded regional temperature datasets}

315 Because of missing data and lack of simultaneous recording between temperature equipment at

316 Lopé we also downloaded two widely used gridded regional data products with which to

317 compare the Lopé data: daily minimum air temperature from the Gridded Berkeley Earth Surface

318 Temperature Anomaly Field ( $1^{\circ}$ resolution; Rohde et al. 2013) and monthly mean daily

319 minimum temperature from the Climate Research Unit's Time-Series v4.01 of high-resolution

320 gridded data (CRU TS4.01; 0.5 resolution; University of East Anglia Climatic Research Unit et

321 al. 2017; Harris et al. 2014). Both were downloaded from http://climexp.knmi.nl/start.cgi for the

322 grid-cell overlapping the SEGC location $(0.2 \mathrm{~N}, 11.6 \mathrm{E})$.

\section{Ocean Sea Surface Temperatures (SSTs)}

324 We downloaded data for four oceanic SST indices from commonly used data sources: the

325 Multivariate ENSO Index (MEI; Wolter \& Timlin 1993; Wolter \& Timlin 1998) sourced from 
326 the NOAA website (https://www.esrl.noaa.gov/psd/enso/mei/index.html), the Indian Ocean

327 Dipole (IOD) Dipole Mode Index (Saji \& Yamagata 2003) sourced from the NOAA website

328 (https://www.esrl.noaa.gov/psd/gcos_wgsp/Timeseries/DMI/) and deseasonalised SSTs for the

329 tropical north Atlantic (NATL, $5^{\circ}-20^{\circ} \mathrm{N}, 60^{\circ}-30^{\circ} \mathrm{W}$ ) and the south equatorial Atlantic (SATL,

$\left.3300^{\circ}-20^{\circ} \mathrm{S}, 30^{\circ} \mathrm{W}-10^{\circ} \mathrm{E}\right)$ sourced from the NOAA National Weather Service Climate Prediction

331 Center (http://www.cpc.ncep.noaa.gov/data/indices/). We rescaled all four SST indices by

332 subtracting the mean and dividing by one standard deviation to allow direct comparison of their

333 effects. Positive values for MEI indicate El Niño conditions; positive values for NATL and

334 SATL indicate warm SSTs in those regions while positive values for IOD indicate cool SSTs in

335 South Eastern equatorial Indian Ocean and warm SSTs in the Western equatorial Indian Ocean.

\section{Analyses}

337 Seasonality

338 To characterise the seasonality of each weather variable we calculated mean values from

339 empirical daily data at three different scales: the mean value for each day of the calendar year

340 (DOY, fine-scale), the ten-day running mean of DOY (medium-scale) and the mean value for

341 each calendar month (coarse-scale). To formally assess the periodicity of each variable we used

342 Fourier analysis. The Fourier transform is a form of spectral analysis used to calculate the

343 relative strength of all possible regular cycles in time series data (Bush et al. 2017). We created

344 standardized, complete time series by filling missing values in monthly time series using the

345 mean value for the corresponding calendar month and standardizing the data by subtracting the

346 mean and dividing by its standard deviation. We then computed the Fourier transform for each

347 time series using the spectrum function from the R Stats package (R Core Team, 2019) and

348 inspected the spectra plots for peaks that represent strong regular cycles in the data (Bush et al.

349 2017).

\section{Long-term trends}

351 We used a linear regression framework to test whether rainfall and minimum temperature had

352 changed over the observation period (1984-2018) using non-interpolated daily data. We fitted

353 compound Poisson generalized linear mixed models (CPGLMM) for daily rainfall and linear

354 mixed models (LMM) for minimum daily temperature to account for their respective data

355 distributions. CPGLMMs are exponential dispersion models based on the Tweedie distribution

356 and are recommended for daily or monthly rainfall data which is positive and continuous with

357 many exact zeros (Hasan and Dunn 2010). We fit CPGLMMs using the cplm R package (Zhang

358 2013) and LMMs using the lme4 $\mathrm{R}$ package (Bates et al. 2015). DOY was included as a random

359 intercept in all models to account for seasonality and the hierarchical structure of the data. We

360 fitted initial models with Year (continuous, rescaled) as the predictor (representing long-term

361 change) and compared these to intercept-only models (representing no long-term change)

362 preferring simple models (few parameters) with lowest AIC (significantly different if delta AIC

363 2). See R-style model notation below with $\varepsilon$ representing residual error not accounted for by the

364 predictors of the model. 
365

366

367

368

369

370

371

372

373

374

375

376

377

378

379

380

381

382

383

384

385

386

387

388

389

390

391

392

393

394

395

396

397

398

399

400

401

402

(1) Daily Rainfall $\sim$ Year $+(1 \mid \mathrm{DOY})+\varepsilon$

(2) Daily Rainfall $\sim 1+(1 \mid \mathrm{DOY})+\varepsilon$

(3) Minimum Daily Temperature $\sim$ Year $+(1 \mid \mathrm{DOY})+\varepsilon$

(4) Minimum Daily Temperature $\sim 1+(1 \mid \mathrm{DOY})+\varepsilon$

We repeated the same procedure for gridded temperature data for Lopé from the daily Berkeley and monthly CRU datasets. DOY was included as a random intercept within the models with daily response data and Month was included as a random intercept within the models with monthly response data.

(5) Minimum Daily Temperature (Berkeley) $\sim$ Year $+(1 \mid$ DOY $)+\varepsilon$

(6) Minimum Daily Temperature (Berkeley) $\sim 1+(1 \mid \mathrm{DOY})+\varepsilon$

(7) Mean Monthly Minimum Daily Temperature (CRU) $\sim$ Year $+(1 \mid$ Month $)+\varepsilon$

(8) Mean Monthly Minimum Daily Temperature (CRU) $\sim 1+(1 \mid$ Month $)+\varepsilon$

Next we investigated whether trends in rainfall and minimum temperature at Lopé differed by season. Various seasonal definitions are used throughout the tropics, usually related to the annual rainfall cycle. We defined our seasons according to Lopé rainfall climatology where the long dry season extends into September, i.e. October-November (ON, the short rainy season), DecemberFebruary (DJF, the short dry season), March-May (MAM, the long rainy season) and JuneSeptember (JJAS, the long dry season; Fig. 2A). We included Year (continuous, rescaled), Season (factor with four levels as above) and their interaction as predictors in initial models to represent long-term change varying by season. We fitted subsequent models without the interaction term to represent long-term change not varying by season and compared the models using AIC values. DOY was included as a random intercept in all models, as before.

(9) Daily Rainfall $\sim$ Season + Year + Season: Year $+(1 \mid$ DOY $)+\varepsilon$

(10) Daily Rainfall $\sim$ Season + Year $)+(1 \mid$ DOY $)+\varepsilon$

(11) Minimum Daily Temperature $\sim$ Season + Year + Season: Year $+(1 \mid$ DOY $)+\varepsilon$

(12) Minimum Daily Temperature $\sim$ Season + Year $+(1 \mid$ DOY $)+\varepsilon$

To estimate the magnitude of the trend in each season, rather than comparing to the global intercept, we modified the best models by temporarily removing the global intercept. For all models described above we inspected the residuals to check for temporal autocorrelation using the R package itsadug (van Rij 2017). None of the median autocorrelation functions (autocorrelation calculated for each DOY or Month respectively) showed significant temporal autocorrelation.

Peer) reviewing PDF | (2019:05:37246:2:0:NEW 28 Jan 2020) 


\section{Periodicity over time}

We used Wavelet analyses to assess if and how the periodicities of the rainfall and temperature time series have changed over time. The Wavelet transform extends the Fourier transform into the time-frequency domain and allows identification of cyclic behavior that may be transient or change over time (Torrence and Compo 1998). We used the complete, standardised monthly time series for rainfall and minimum temperature (with missing values interpolated from the long-term calendar month mean) and computed the Wavelet transform using the function $w t$ from the R package biwavelet (Gouhier et al. 2018). From the wavelet transform we plotted the power (higher power denotes greater fidelity to a certain cycle), significance (a cycle is significant if $>0.95, \mathrm{X}^{2}$ test) and cone of influence (denoting the unreliable region at the beginning and end of the time series due to edge effects). We extracted the power of the biannual, annual and multiannual (mean of the 2-4 year periods) components from the wavelet spectra to further assess how these dominant cycles have varied over time and contributed to the trend (Adamowski et al. 2009). We constrained the upper limit of the multiannual component to four years because longer cycles were heavily influenced by edge effects.

\section{Oceanic influences}

We used wavelet coherence to assess if and how the local weather system at Lopé is associated with SSTs of the major oceans at interannual scales (Pacific: MEI, Indian Ocean: IOD and Atlantic Ocean: NATL and SATL). Wavelet coherence is an approach derived from bivariate wavelet analysis and calculates a measure of the correlation (from 0 to 1 ) between two time series ( $\mathrm{x}$ and $\mathrm{y}$ ) at all periodicities through time. Wavelet coherence can be used to identify common oscillatory behavior, even if that behavior is inconsistent (i.e. the time series are "nonstationary"; Grinstead, et al. 2004). According to Grinstead, et al. (2004), strong coherence and consistent phase relationships between two carefully selected time series indicate that there may be a causative relationship. In this study we computed wavelet coherence for all eight combinations of $x$ (rainfall or minimum temperature monthly time series) against y (MEI, IOD, NATL or SATL monthly time series) using the function wtc from the R package biwavelet (Tarik, et al. 2019) with 1000 Monte Carlo randomisations. To summarise and compare the wavelet coherence between each time series pair we calculated the "global" time-averaged coherence for each period (Chang, et al. 2019).

$\mathrm{R}$ code to accompany all analyses described above is made available in Supplemental Information (Code S1). Permission to conduct this research in Gabon was granted by the Centre International de Recherches Medicales de Franceville (CIRMF) Scientific Council and the Ministry of Water and Forests (1986 - 2010), and by Gabonese National Parks Agency (ANPN) and the National Centre for Research in Science and Technology (CENAREST; 2010 - present).

\section{Results}

\section{Seasonality}


441 Mean total annual rainfall at Lopé from 1984-2018 was $1466 \mathrm{~mm} \pm 201 \mathrm{sd}$. Rainfall in this 442 period followed a biannual cycle (Fig. S1) with broad peaks in the rainy seasons (MAM and ON) 443 when mean daily rainfall was always greater than $5 \mathrm{~mm}$ (Fig. 2A). The long dry season (JJAS) 444 was very consistent, with a 90-day period (mid-June to mid-September) in which the ten-day 445 running mean was never greater than $1 \mathrm{~mm}$ (Fig. 2A). The short dry season (DJF) by contrast 446 was much less dry (ten-day running mean greater than $1 \mathrm{~mm}$ ) and more variable between years 447 (Fig. 2A).

448 Mean daily maximum and minimum temperatures at Lopé were $28.1^{\circ} \mathrm{C} \pm 2.2 \mathrm{sd}$ and $21.9^{\circ} \mathrm{C} \pm$ $4491.1 \mathrm{sd}$ respectively at the forest site $(1984-2018)$ and $31.6^{\circ} \mathrm{C} \pm 2.9 \mathrm{sd}$ and $22.0^{\circ} \mathrm{C} \pm 1.2 \mathrm{sd}$ at the 450 savanna site (2002-2018). Daily temperature range was greater in the savanna than under the 451 forest canopy (Fig. 2C and 2D). Maximum daily temperature in the forest showed strong annual and bi-annual cycles while in the savanna only the annual cycle appeared dominant (Fig. S1). The difference between the two sites occurred during the short dry season when temperatures were maintained in the savanna at similar levels to the rainy seasons (ten-day running mean always greater than $31.7^{\circ} \mathrm{C}$ from October to May in the savanna; Fig. 2C). In the forest, the highest peaks in maximum daily temperature occurred in April and September (mean monthly maximum daily temperatures were $29.5^{\circ} \mathrm{C}$ and $28.6^{\circ} \mathrm{C}$ respectively; Fig. 2D). Annual cycles dominated the minimum daily temperature record for both the forest and the savanna (Fig. S1). Minimum daily temperatures were relatively constant from September to June $\left(\sim 22.5^{\circ} \mathrm{C}\right)$ followed by a cool period during the long dry season reaching an annual trough in July (mean monthly minimum daily temperature is $20.6^{\circ} \mathrm{C}$ in both the savanna and forest; Fig. $2 \mathrm{C}$ and D). The forest was more humid than the savanna throughout the year (mean absolute humidity is $21.40 \mathrm{~g} / \mathrm{m}^{3}$ and $20.35 \mathrm{~g} / \mathrm{m}^{3}$ respectively; Fig. $2 \mathrm{E}$ and F). Humidity follows the same annual cycle in both locations (Fig. S1), dropping during the long dry season to reach a minima in August and increasing throughout the short rains $(\mathrm{ON})$ to reach a plateau from January to May (Fig. 2E and F).

Both surface solar radiation and wind speed were dominated by annual cycles at Lopé (Fig. S1), with the long dry season coinciding with low irradiance (mean monthly solar radiation for July = $129.3 \mathrm{~W} / \mathrm{m} 2$; Fig. 2G) and elevated wind speeds (mean monthly wind speeds for August and September are $1.3 \mathrm{~m} / \mathrm{s}$ and $1.4 \mathrm{~m} / \mathrm{s}$ respectively; Fig. 2B). Aerosol optical depth cycled twice yearly (Fig. S1), being elevated during the dry seasons and suppressed during the rainy seasons (Fig. 2H). In contrast to the solar radiation cycle, which reached its minima during the long dry season (JJAS), the strongest peak in aerosol optical depth occurred in the short dry season (mean monthly aerosol optical depth at $500 \mathrm{~nm}$ for February $=0.97$ ). Aerosol optical depth at 440 and $675 \mathrm{~nm}$ wavelengths is similar to that at $500 \mathrm{~nm}$ (Fig. S2).

\section{Long-term trends}

477 Total annual rainfall decreased by $-75 \mathrm{~mm}$ per decade, a change of $-5.5 \%$ relative to mean annual rainfall for the time period (CPGLMM, Estimated index parameter $=1.6$, Estimated dispersion parameter $=9.7$, Estimate $=-0.05, \mathrm{SE}=0.02, \mathrm{Z}=-2.22,95 \% \mathrm{CI}=-0.10:-0.01$; Table 3 and Fig. 
481 change in daily rainfall in DJF and ON and significant decline in JJAS (-0.07 $\mathrm{mm}$ per day per 482 decade, equating to $-6.35 \%$ of mean JJAS daily rainfall).

483 Minimum daily temperature at Lopé increased at a rate of $+0.25^{\circ} \mathrm{C}$ per decade, equivalent to $484+1.1 \%$ relative to mean minimum temperature for the time period $(\mathrm{LMM}$, Estimate $=0.24 ; \mathrm{SE}=$ $485 \quad 0.01 ; \mathrm{T}=24.84 ; 95 \%$ Confidence Interval $=0.22: 0.26$; Table 3 and Fig. 3B). The rate of 486 warming also varied by season (Tables 4 and 5 ) with minimum temperature increasing most 487 quickly in $\mathrm{ON}$ and $\mathrm{DJF}\left(+0.31^{\circ} \mathrm{C}\right.$ and $+0.30^{\circ} \mathrm{C}$ per decade respectively) and most slowly in JJAS $488 \quad\left(+0.18^{\circ} \mathrm{C}\right.$ per decade).

489 Berkeley minimum daily temperature for the interpolated Lopé grid square ( $1^{\circ}$ resolution) 490 increased at a rate of $+0.16^{\circ} \mathrm{C}$ per decade $(\mathrm{LMM}$, Estimate $=0.34, \mathrm{SE}=0.01, \mathrm{~T}=23.4,95 \%$ 491 Confidence Interval $=0.31: 0.37)$ while the $\mathrm{CRU}$ interpolated record $\left(0.5^{\circ}\right.$ resolution $)$ increased 492 by $+0.19 \mathrm{Cc}$ per decade $(\mathrm{LMM}$, Estimate $=0.63 \mathrm{SE}=0.06, \mathrm{~T}=11.2,95 \%$ Confidence Interval $=$ 493 0.52: 0.74).

\section{Periodicity over time}

495 Wavelet analyses gave further indication of the nature of these changes. The dominant six-month 496 cycle for rainfall was, on average, four times as powerful as the annual component and 66 times 497 as powerful as the multi-annual component and remained significant for most of the time period 498 (Fig. 3C). However, the signal of the biannual cycle decreased on three occasions (1996-97, 4992004 and 2006; Fig. 3C). Over time, the signal of the biannual rainfall cycle appeared to 500 decrease while the annual cycle strengthened (Fig. 3E). The annual cycle for minimum

501 temperature was, on average, three times as powerful as the biannual component and 23 times as 502 powerful as the multi-annual component (Fig. 3F). The signal of the annual cycle remained 503 dominant throughout most of the time period with patches of low power at the end of the 1980s 504 and between 2007 and 2010 (Fig. 3D). There were patches of high power in the multiannual 505 component around 2000. The signal of both the annual and semi-annual components appear to 506 have been increasing in strength over time (Fig. 3F).

\section{Oceanic influences}

508 Wavelet coherence analyses showed that the ENSO index (MEI) had the strongest coherence 509 with both rainfall and temperature at Lopé over the last three decades at multi-annual scales (2-4 510 years; Fig. 4 and Fig. S3). However, the influence of ENSO has been patchy through time; 511 Coherence between ENSO and rainfall was particularly strong pre-1990 and between 2007 and 5122012 (Fig. 4A) while coherence between ENSO and minimum temperature was fairly consistent 513 up to 2000 and has become weaker since (Fig. 4B). SSTs of the southern tropical Atlantic 514 showed strong coherence with Lopé rainfall pre-2000 while SSTs of the northern tropical 515 Atlantic showed strong coherence with Lopé rainfall post-2000 at multi-annual scales (4-8 years; 516 Fig. 4C and E and Fig. S3). SATL cycled in phase with Lopé rainfall (arrows point to the right) 517 while NATL cycles in anti-phase during the 2005 to 2010 period (arrows point to the left; 518 Figures $4 \mathrm{C}$ and $\mathrm{E}$ ). Within the reliable region of the wavelet coherence plots (away from edge 
519 effects) the IOD does not appear to have had a particularly strong or consistent relationship with 520 either rainfall or temperature at Lopé (Fig. 4G and H and Fig. S3).

\section{Discussion}

\section{Our results}

523 Lopé weather has changed significantly over the last three decades, warming at a rate of $+0.25^{\circ} \mathrm{C}$ 524 per decade (minimum daily temperature) and drying at a rate of $-75 \mathrm{~mm}$ per decade (total annual 525 rainfall; Figure 3A and 3B). Both trends are seasonally dependent (Table 4); with significant 526 warming occurring in all seasons, being most pronounced from October to February (see model estimates in Table 5). The rainfall decline occurred predominately between March and September, incorporating both the long rainy season and the long dry season (see model estimates in Table 5). The drying trend at Lopé supports observations of reduced Ogooué river flow from March to September (Mahe et al. 2013) and precipitation declines evident from gridded gauge-data for the Gabon/Cameroon region (-1\% total annual rainfall, 1968-1998; Malhi $\&$ Wright 2004). However, the Lopé total annual rainfall decline of $-5.5 \%$ per decade exceeds the trend estimated from the regional gauge-data. While the strength of the biannual cycle in rainfall appears to be declining at Lopé along with the overall long-term trend, the annual component is getting more powerful. Declines in rainfall in the long dry season (JuneSeptember) but not the short dry season (December-February) are likely to be contributing to an increased contrast between the two dry seasons and enhancing the overall annual rainfall cycle (Table 5).

The warming trend recorded at Lopé is greater than that estimated for the location over the same time period using the Berkeley and CRU gridded datasets $\left(+0.16^{\circ} \mathrm{C}\right.$ and $+0.19^{\circ} \mathrm{C}$ respectively) and that identified using satellite data for mean annual temperature for all tropical Africa $\left(+0.15^{\circ} \mathrm{C}, 1979-2010\right.$; Collins 2011). However, it is lower than the change estimated from gridded observational data (CRU) for mean annual temperature specifically for African tropical forests $\left(+0.29^{\circ} \mathrm{C}\right.$ per decade, 1976-1998; Malhi \& Wright 2004). While there remain issues with the Lopé temperature data record (lack of simultaneous recording to calibrate data recorded using different equipment), there is good evidence from supporting datasets and the literature that the warming trend observed at the site since 1984 is real. The slower warming trend in the already cool, long dry season is likely to account for the apparent increase in the power of the annual cycle for Lopé minimum temperature. Our analysis of seasonality at Lopé further serves to emphasise the ecological importance of the long dry season in western equatorial Africa; three to four months of dry (almost no rainfall for 90 consecutive days), cool (mean maximum daily temperature is $2.5^{\circ} \mathrm{C}$ lower in July compared to April) and windy conditions with low humidity and limited light availability (Figure 2). Such a defined dry season poses specific constraints to the biota and is likely to act as a temporal marker for ecological events, similar to a winter event in temperate regions, while the response of the plant community to recurrent and predictable seasonal drought during the long dry season 
557 could be used to estimate the long-term response to drying over multi-annual time scales (Detto 558 et al. 2018).

559 Reduced light availability during the long dry season in the Gabon region is most strongly 560 associated with seasonal low-level cloud cover (Philippon et al. 2019). Aerosol load may also 561 have a seasonal influence on light availability as aerosol optical depth and solar radiation appear 562 to cycle in anti-phase although we are not able to tease apart their relative importance in this 563 analysis (Figure 2). Low direct solar radiation and cool temperatures will reduce water demand 564 during these months (e.g. potential evapotranspiration is less than $2.3 \mathrm{~mm}$ per day during the long 565 dry season in SW Gabon; Philippon et al. 2019) and are likely contributors to the forest's ability

566 to maintain an evergreen canopy despite seasonal drought. Unsurprisingly, the savanna and

567 forest experience different microclimates because the forest canopy creates a more humid, cooler 568 climate throughout the year with a reduced range between daytime and night-time temperatures (Figure 2). It is possible that the forest may also directly enhance water supply for plants during periods of low precipitation / high cloud cover due to foliar interception of low-lying clouds. At another tropical forest site ( $\sim 1000 \mathrm{~m}$ above sea level), foliar interception has shown to contribute an additional $40 \%$ of moisture compared to rainfall (Hutley et al. 1997) meaning that rain gauge data does not always accurately represent the water balance of the forest ecosystem (Philippon $e t$ al. 2019). While we do not have information on foliar interception of clouds at our study site ( $\sim 280 \mathrm{~m}$ above sea level), the hydroclimatic conditions of the region do not predict occurrence of cloud-affected forest here (Oliveira et al. 2014). We can assume that the impact of cloud interception on water supply is negligible, although it may occur on forested hills above $600 \mathrm{~m}$

578 (e.g. the hill local to the study station known as The Camel which reaches $678 \mathrm{~m}$ ) and a dedicated research agenda would be needed to assess the any direct contribution of clouds to moisture availability, especially during the cloudy dry seasons.

581

582

We have also shown that variability in temperature and rainfall at our site is strongly influenced by global weather patterns. The most important influence on Lopé temperature is the Pacific ENSO index, with our analysis showing strong coherence between these two datasets on multiannual scales, especially pre-2000 (Figure 4). This result is supported by a continent-wide study showing warming throughout Africa in El Nino years (Collins 2011). None of the other oceanic indices appeared to influence Lopé temperature in a consistent way (Figure 4). As for Lopé rainfall, the most important influence appears to be the tropical Atlantic. Rainfall cycled in phase with southern tropical Atlantic SSTs pre-2000 and in anti-phase with northern tropical Atlantic SSTs post-2000 on multi-annual scales (Figure 4). The phase relationships between these data series indicate that higher than average rainfall at Lopé coincides with warm conditions in the south tropical Atlantic and cool conditions in the north tropical Atlantic. This result is supported by a number of other studies; Camberlin et al. (2001) show the Atlantic dipole (cool temperatures in the north Atlantic and warm temperatures in the south tropical Atlantic) to be associated with higher than average rainfall in the region during March-May. Similarly, Balas at al. (2007) and Otto et al. (2013) demonstrate how warm conditions in the southern equatorial 
597 Atlantic (especially the Benguela coast) coincide with enhanced rainfall in the region during the

598 dry seasons. ENSO also appears to have some influence on Lopé rainfall although the

599 relationship is patchy (Figure 4). The anti-phase relationship during periods of strong coherence

600 in our analysis indicate that rainfall decreases at Lopé during El Nino events. A similar result

601 was found among the major studies summarized in Table 1. Finally, we found little evidence of

602 the influence of the Pacific Ocean on Lopé rainfall despite published data showing reduced

603 rainfall in western equatorial Africa coinciding with positive IOD modes (Dezfuli \& Nicholson

604 2013; Nicholson \& Dezfuli 2013; Otto et al. 2013).

605

606 Model projections of future rainfall in western equatorial Africa cover a broad spectrum and as a 607 result, averaged model trends are close to zero. However, those models that predict drying in the 608 region incorporate a northward shift of the rainbelt, related to cool conditions in the Gulf of 609 Guinea (the Atlantic Cold Tongue; James et al. 2013 and Fig. 1). The strong coherence between 610 Lopé rainfall and SSTs of the southern equatorial Atlantic $\left(0^{\circ}-20^{\circ} \mathrm{S}\right)$ at multi-annual scales in

611 our study provides some support for the mechanisms behind these "dry" models. Indeed, Atlantic

612 SSTs and circulation patterns have been an important influence on Congo Basin precipitation for

613 the past 20,000 years (Schefuss et al. 2005). Overall, our work supports the idea that the drivers

614 of rainfall variability in western equatorial Africa are highly complex, with strong local and

615 seasonal forcing from the major oceans. Land topography (e.g. the highlands of Gabon,

616 Cameroon and eastern Africa) is also likely to be a major influence on highly localised

617 expressions of rainfall and rainfall variability in the region (Balas et al. 2007; Dezfuli et al.

618 2015).

619 Data quality and availability

620 One of the major issues with climate analyses in Central Africa is the already limited and

621 declining amount of publicly available data from weather stations in the region: The nearest

622 weather stations to Lopé listed on the Global Historical Climatology Network (GCHN) Daily

623 Database (Menne et al. 2012) are between 136 and $185 \mathrm{~km}$ away and there are no public data

624 available since 1980. The World Meteorological Organisation has a minimum recommended

625 density of weather stations eight times higher than the modern density of weather stations in

626 Africa (Collins 2011). This lack of data has a direct impact on the quality of gridded climate data

627 products (Suggitt et al. 2017) and leads to an inability to calculate daily climatic indices for the

628 extremes (Niang et al. 2014). Gabon is also one of the cloudiest places on earth

629 (http://www.acgeospatial.co.uk/the-cloudiest-place/) which leads to large uncertainties in

630 satellite estimates, with some satellite algorithms overestimating rainfall in the region by at least

631 a factor of two (Balas et al. 2007). Finally, poor correlation between Central African rainfall and

632 neighbouring regions, as well as variability between individual stations, suggests much local

633 influence and further confounds the challenges of sparse data (Balas et al. 2007).

634 The importance of maintaining long-term study sites and improving the quality and type of

635 weather measurements in the region has been known for some time (Clark 2007). However, the

636 region is remote and there are many financial, logistical and political challenges to face when 
637 servicing field stations. One such issue is that western equatorial Africa has the highest

638 frequency of lightning strike in the world (Balas et al. 2007) leading to difficulties and great

639 expense maintaining equipment. Lightning damage is an issue regularly confronted at Lopé and

640 has led to major gaps in our data record. While automatic continuous measurements can provide

641 vast amounts of detailed data relevant for ecological studies, they are also inherently more

642 susceptible to technical failures that need expert fixes. In our experience, data gaps are more

643 likely to go unnoticed with automatic data collection and so while we welcome new automatic

644 methods, we recommend maintaining long-term manual records alongside for consistency.

645

\section{Conclusions}

647 The long-term Lopé weather record has not previously been made public and is of high value in such a data poor region. Our results support regional analyses of climatic seasonality, long-term

649 warming and the influences of the oceans on temperature and rainfall variability. However, there

650 are some surprises; warming has occurred more rapidly than the regional products suggest and while there remains much uncertainty in the wider region, reduced rainfall over the last three

652 decades at Lopé is in agreement with drying trends evident from less recent observational data

653 for western equatorial Africa. The influence of the southern equatorial Atlantic (Atlantic cold

654 tongue) on rainfall at Lopé lends support to the mechanism behind "dry" models of future

655 rainfall in the region.

656 With a climatic regime delivering on average less than $1500 \mathrm{~mm}$ per year, Lopé is a globally

657 anomalous region for the persistence of evergreen tropical forest (Reich 1995). Reduced water

658 demand during the cloudy, light-deficient long dry season is likely to be the major factor

659 facilitating persistence of evergreen forests despite seasonal drought (Philippon 2019). It is

660 essential that we understand the sensitivity of this seasonal cloudiness to ocean temperatures, and

661 the viability of forest in this dry region should the clouds disappear and thus water demand

662 increase during the seasonal drought.

663 We know from historic analyses that, while forests in this region have been resilient to certain

664 levels of climatic change, they have also been susceptible to shifts back and forth between

665 evergreen humid forests and open, fire-prone, dry forest systems and even savannas when

666 changes tip over certain thresholds (Brncic et al. 2006; Willis et al. 2013). The community shifts

667 associated with drier and warmer climates have often been non-linear and dependent on

668 ecosystem-specific resilience at local and regional scales (Willis et al. 2013). Carbon fertilisation

669 and dry season cloudiness may be shielding African humid forests from the impacts of drying

670 and warming at present. However, we urgently need reliable information on current climate and

671 forest function and reduced uncertainties in future projections of change to inform climate

672 change risk assessments for the western equatorial region of Central Africa.

673

674

\section{Acknowledgements}

675 We acknowledge significant periods of independent data collection undertaken by Richard

676 Parnell, Edmond Dimoto and Lee White. 


\section{References}

679 Abernethy, K., Maisels, F. \& White, L.J.T. (2016). Environmental Issues in Central Africa. Annual Review of Environment and Resources, 41, 1-33.

681

Adamowski, K., Prokoph, A. \& Adamowski, J. (2009). Development of a new method of wavelet

682

683

684

685

686

687 aided trend detection and estimation. Hydrological Processes, 23, 2686-2696.

Asefi-najafabady, S. \& Saatchi, S. (2013). Response of African humid tropical forests to recent rainfall anomalies. Philosophical transactions of the Royal Society of London. Series B, Biological sciences, 368, 20120306,.

Balas, N., Nicholson, S.E. \& Klotter, D. (2007). The relationship of rainfall variability in West Central Africa to sea-surface temperature fluctuations. International Journal of Climatology, 27, 1335-1349.

Barlow, J., França, F., Gardner, T.A., Hicks, C.C., Lennox, G.D., Berenguer, E., Castello, L., Economo, E.P., Ferreira, J., Guénard, B., Gontijo Leal, C., Isaac, V., Lees, A.C., Parr, C.L., Wilson, S.K., Young, P.J. \& Graham, N.A.J. (2018). The future of hyperdiverse tropical ecosystems. Nature, 559, 517-526.

Bates, D., Maechler, M., Bolker, B. and Walker, S. (2015). Fitting Linear Mixed-Effects Models Using lme4. Journal of Statistical Software, 67(1), 1-48. doi:10.18637/jss.v067.i01.

Behera, S., Brandt, P. \& Reverdin, G. (2013). The tropical ocean circulation and dynamics. International Geophysics vol. 103, pp. 385-412. Academic Press.

Bloomfield, P. (2000). Fourier analysis of time series: an introduction. John Wiley \& Sons.

Bonan, G.B. (2008). Forests and climate change: forcings, feedbacks, and the climate benefits of forests. Science (New York, N.Y.), 320, 1444-1449.

Borchert, R., Renner, S.S., Calle, Z., Havarrete, D., Tye, A., Gautier, L., Spichiger, R. \& Von Hildebrand, P. (2005). Photoperiodic induction of synchronous flowering near the Equator. Nature, 433, 627-629.

Brncic, T.M., Willis, K.J., Harris, D.J. and Washington, R., 2006. Culture or climate? The relative influences of past processes on the composition of the lowland Congo rainforest. Philosophical Transactions of the Royal Society B: Biological Sciences, 362(1478), pp.229-242.

Bush, E.R., Abernethy, K.A., Jeffery, K., Tutin, C., White, L., Dimoto, E., Dikangadissi, J.T., Jump, A.S. \& Bunnefeld, N. (2017). Fourier analysis to detect phenological cycles using tropical field data and simulations. Methods in Ecology and Evolution, 8, 530-540.

Cai, J., 2018. humidity: Calculate Water Vapor Measures from Temperature and Dew Point. R package version 0.1.4. Available at: https://github.com/caijun/humidity.

Camberlin, P., Janicot, S. \& Poccard, I. (2001). Seasonality and atmospheric dynamics of the teleconnection between African rainfall and tropical sea-surface temperature: Atlantic vs. ENSO. International Journal of Climatology, 21, 973-1005. 
715 Chang, X., Wang, B., Yan, Y., Hao, Y. and Zhang, M., 2019. Characterizing effects of monsoons

716

717

718

719

720

721

722

723

724

725

726

727

728

729

730

731

732

733

734

735

736

737

738

739

740

741

742

743

744

745

746

747

748

749

750

751

752

753

754 and climate teleconnections on precipitation in China using wavelet coherence and global coherence. Climate Dynamics, 52(9-10), pp.5213-5228.

Clark, D.A. (2007). Detecting Tropical Forests ' Responses to Global Climatic and Atmospheric Change: Current Challenges and a Way Forward. 39, 4-19.

Collins, J.M. (2011). Temperature variability over Africa. Journal of Climate, 24, 3649-3666.

Cusack, D., Karpman, J., Ashdown, D., Cao, Q., Ciochina, M., Halternman, S., Lydon, S. \& Neupane, A. (2013). Global change effects on humid tropical forests: Evidence for biogeochemical and biodiversity shifts at an ecosystem scale. Review of Geophysics, 54, 523-610.

Detto, M., Wright, S.J., Calderón, O. \& Muller-landau, H.C. (2018). Resource acquisition and reproductive strategies of tropical forest in response to the El Niño-Southern Oscillation. Nature Communications, 9, 913.

Dezfuli, A.K. \& Nicholson, S.E. (2013). The Relationship of Rainfall Variability in Western Equatorial Africa to the Tropical Oceans and Atmospheric Circulation . Part II : The Boreal Autumn. Journal of Climate, 26, 66-84.

Nicholson, S.E. (2018). The ITCZ and the seasonal cycle over equatorial Africa. Bulletin of the American Meteorological Society, 99, 337-348.

Nicholson, S.E. \& Dezfuli, A.K. (2013). The Relationship of Rainfall Variability in Western Equatorial Africa to the Tropical Oceans and Atmospheric Circulation . Part I : The Boreal Spring. Journal of Climate, 26.

Nicholson, S.E., Funk, C. \& Fink, A.H. (2018). Rainfall over the African continent from the 19th through the 21st century. Global and Planetary Change, 165, 114-127.

Otto, F.E.L., Jones, R.G., Halladay, K. \& Allen, M.R. (2013). Attribution of changes in precipitation patterns in African rainforests. Philosophical transactions of the Royal Society of London. Series B, Biological sciences, 368, 20120299.

Dezfuli, A.K., Zaitchik, B.F. \& Gnanadesikan, A. (2015). Regional atmospheric circulation and rainfall variability in south equatorial Africa. Journal of Climate, 28, 809-818.

Dommo, A., Philippon, N., Vondou, D.A., Seze, G. \& Eastman, R. (2018). The June - September Low Cloud Cover in Western Central Africa : Mean Spatial Distribution and Diurnal Evolution. 31, 9585-9603.

Farnsworth, A., White, E., Williams, C.J.R., Black, E. \& Kniveton, R. (2011). Understanding the Large Scale Driving Mechanisms of Rainfall Variability over Central Africa. African Climate and Climate Change, pp. 101-122. Springer, Dordecht.

Fauset, S., Baker, T.R., Lewis, S.L., Feldpausch, T.R., Affum-Baffoe, K., Foli, E.G., Hamer, K.C. and Swaine, M.D., 2012. Drought-induced shifts in the floristic and functional composition of tropical forests in Ghana. Ecology letters, 15(10), pp.1120-1129.

Gond, V., Fayolle, A., Pennec, A., Cornu, G., Mayaux, P., Doumenge, C., Fauvet, N., Gourletfleury, S., B, P.T.R.S. \& Camberlin, P. (2013). Vegetation structure and greenness in Central Africa from Modis multi-temporal data. Philosophical transactions of the Royal 
755

756

757

758

759

760

761

762

763

764

765

766

767

768

769

770

771

772

773

774

775

776

777

778

779

780

781

782

783

784

785

786

787

788

789

790

791

792

793

794

Society of London. Series B, Biological sciences, 368, 20120309.

Gouhier, T.C., Grinsted, A. \& Simko, V. (2018). R package biwavelet: Conduct Univariate and Bivariate Wavelet Analyses.

Grinsted, A., Moore, J.C. and Jevrejeva, S., 2004. Application of the cross wavelet transform and wavelet coherence to geophysical time series. Nonlinear processes in geophysics, 11(5/6), pp.561-566

Guan, K., Wolf, A., Medvigy, D., Caylor, K., Pan, M. \& Wood, E.F. (2013). Seasonal coupling of canopy structure and function in African tropical forests and its environmental controls. Ecosphere, 4, 1-21.

Habib, E., Krajewski, W.F. \& Ciach, G.J. (2001). Estimation of Rainfall Interstation Correlation. Journal of Hydrometeorology, 2, 621-629.

Harris, I., Jones, P.D., Osborn, T.J. \& Lister, D.H. (2014). Updated high-resolution grids of monthly climatic observations - the CRU TS3.10 Dataset. International Journal of Climatology, 34, 623-642.

Hartmann, D.L., Klein Tank, A.M.G., Rusticucci, M., Alexander, L. V., Brönnimann, S., Charabi, Y.A.R., Dentener, F.J., Dlugokencky, E.J., Easterling, D.R., Kaplan, A., Soden, B.J., Thorne, P.W., Wild, M. \& Zhai, P. (2013). Observations: Atmosphere and surface. Climate Change 2013 the Physical Science Basis: Working Group I Contribution to the Fifth Assessment Report of the Intergovernmental Panel on Climate Change (eds T.F. Stocker, D. Qin, G.-K. Plattner, M. Tignor, S.K. Allen, J. Boschung, A. Nauels, Y. Xia, V. Bex \& P.M. Midgley), pp. 159-254. Cambridge University Press, Cambridge, United Kingdom and New York, NY, USA.

Hasan, M.M. and Dunn, P.K., 2010. A simple Poisson-gamma model for modelling rainfall occurrence and amount simultaneously. Agricultural and forest meteorology, 150(10), pp.1319-1330.

Helder, C., Sousa, R. De, Hilker, T., Waring, R., Moura, Y.M. De \& Lyapustin, A. (2017). Progress in Remote Sensing of Photosynthetic Activity over the Amazon Basin. Remote Sensing, 9, 148.

Holben, B.N., Eck, T.F., Slutsker, I., Tanré, D., Buis, J.P., Setzer, A., Vermote, E., Reagan, J.A., Kaufman, Y.J., Nakajima, T., Lavenu, F., Jankowiak, I. \& Smirnov, A. (1998). AERONET - A Federated Instrument Network and Data Archive for Aerosol Characterization. Remote Sensing of Environment, 66, 1-16.

Huntingford, C., Zelazowski, P., Galbraith, D., Mercado, L.M., Sitch, S., Fisher, R., Lomas, M., Walker, A.P., Jones, C.D., Booth, B.B. and Malhi, Y., 2013. Simulated resilience of tropical rainforests to $\mathrm{CO} 2$-induced climate change. Nature Geoscience, 6(4), p.268.

Hutley, L.B., Doley, D., Yates, D.J. and Boonsaner, A. (1997). Water balance of an Australian subtropical rainforest at altitude: the ecological and physiological significance of intercepted cloud and fog. Australian Journal of Botany, 45(2), pp.311-329.

James, R. \& Washington, R. (2013). Changes in African temperature and precipitation associated with degrees of global warming. Climatic Change, 117, 859-872. 
795

796

797

798

799

800

801

802

803

804

805

806

807

808

809

810

811

812

813

814

815

816

817

818

819

820

821

822

823

824

825

826

827

828

829

830

831

832

833

834

James, R., Washington, R. \& Rowell, D.P. (2013). Implications of global warming for the climate of African rainforests. Philosophical Transactions of the Royal Society B: Biological Sciences, 368, 20120298,.

Kidd, C., Becker, A., Huffman, G.J., Muller, C.L., Joe, P., Skofronick-Jackson, G. \& Kirschbaum, D.B. (2017). So, how much of the Earth's surface is covered by rain gauges? Bulletin of the American Meteorological Society, 98, 69-78.

Kothe, S., Pfeifroth, U., Cremer, R., Trentmann, J. \& Hollmann, R. (2017). A Satellite-Based Sunshine Duration Climate Data Record for Europe and Africa. Remote Sensing, 9, 429.

Laraque, A., Mahé, G., Orange, D. \& Marieu, B. (2001). Spatiotemporal variations in hydrological regimes within Central Africa during the twentieth century. Journal of Hydrology, 245, 1-4, 104-117.

Lewis, S.L., Sonké, B., Sunderland, T., Begne, S.K., Lopez-gonzalez, G., Heijden, G.M.F. Van Der, Phillips, O.L., Affum-baffoe, K., Baker, T.R., Banin, L., Bastin, J., Beeckman, H., Boeckx, P., Bogaert, J., Cannière, C. De, Clark, C.J., Collins, M., Djagbletey, G., Djuikouo, M.N.K., Doucet, J., Ewango, C.E.N., Fauset, S., Feldpausch, T.R., Ernest, G., Gillet, J., Hamilton, A.C., Harris, D.J., Hart, T.B., Haulleville, T. De, Hladik, A., Hufkens, K., Huygens, D., Jeanmart, P., Jeffery, K.J., Leal, M.E., Lloyd, J., Lovett, J.C., Makana, J., Malhi, Y., Andrew, R., Ojo, L., Peh, K.S., Pickavance, G., Poulsen, J.R., Reitsma, J.M., Sheil, D., Simo, M., Steppe, K., Taedoumg, H.E., Talbot, J., James, R.D., Taylor, D., Thomas, S.C., Toirambe, B., Verbeeck, H., Vleminckx, J., Lee, J., White, T., Willcock, S., Woell, H., Zemagho, L., B, P.T.R.S., Sonke, B., Poulsen, R. \& Thomas, C. (2013). Aboveground biomass and structure of 260 African tropical forests. Philosophical transactions of the Royal Society of London. Series B, Biological sciences, 368, 20120295.

Mahe, G., Lienou, G., Descroix, L., Bamba, F., Paturel, J.E., Laraque, A., Meddi, M., Habaieb, H., Adeaga, O., Dieulin, C., Chahnez Kotti, F. \& Khomsi, K. (2013). The rivers of Africa: Witness of climate change and human impact on the environment. Hydrological Processes, 27, 2105-2114.

Maidment, R.I., Allan, R.P. \& Black, E. (2015). Recent observed and simulated changes in precipitation over Africa. Geophysical Research Letters, 42, 8155-8164.

Maidment, R.I., Grimes, D., Allan, R.P., Tarnavsky, E., Stringer, M., Hewison, T., Roebeling, R. \& Black, E. (2014). The 30-year TAMSAT African Rainfall Climatology And Time-series (TARCAT) Dataset. Journal of Geophysical Research: Atmospheres, 119.18, 10-619.

Maidment, R.I., Grimes, D., Black, E., Tarnavsky, E., Young, M., Greatrex, H., Allan, R.P., Stein, T., Nkonde, E., Senkunda, S. \& Alcántara, E.M.U. (2017). A new, long-term daily satellite-based rainfall dataset for operational monitoring in Africa. Scientific Data, 4, 1-19.

Malhi, Y., Adu-bredu, S., Asare, R.A., Lewis, S.L., Mayaux, P. \& B, P.T.R.S. (2013). The past, present and future of Africa's rainforests. Philosophical transactions of the Royal Society of London. Series B, Biological sciences, 368, 20120293.

Malhi, Y. \& Wright, J. (2004). Spatial patterns and recent trends in the climate of tropical rainforest regions. Philosophical Transactions of the Royal Society B: Biological Sciences, 
$835 \quad 359,311-329$.

836 Menne, M.J., Durre, I., Vose, R.S., Gleason, B.E. \& Houston, T.G. (2012). An Overview of the

837 Global Historical Climatology Network-Daily Database. Journal of Atmospheric and

$838 \quad$ Oceanic Technology, 29, 897-910.

839 Mitchard, E.T.A. (2018). The tropical forest carbon cycle and climate change. Nature, 559, 527$840 \quad 534$.

841 Munzimi, Y., Hansen, M., Adusei, B. \& Senay, G. (2015). Characterizing Congo Basin Rainfall

842 and Climate Using Tropical Rainfall Measuring Mission (TRMM) Satellite Data and

843 Limited Rain Gauge Ground Observations. Journal of Applied Metereology and

$844 \quad$ Climatology, 54, 541-555.

845 Nagai, S., Ichie, T., Yoneyama, A., Kobayashi, H., Inoue, T., Ishii, R., Suzuki, R. \& Itioka, T.

846 (2016). Usability of time-lapse digital camera images to detect characteristics of tree

847 phenology in a tropical rainforest. Ecological Informatics, 32, 91-106.

848 National Weather Service. (2018). Inter-Tropical Convergence Zone. Jet Stream - An Online

849 School for Weather. URL https://www.weather.gov/jetstream/itcz [accessed 3 December

$850 \quad 2018]$

851 Niang, I., Ruppel, O.C., Abdrabo, M.A., Essel, A., Lennard, C., Padgham, J. \& Urquhart, P.

852 (2014). Africa. Climate Change 2014: Impacts, Adaptation and Vulnerability -

853 Contributions of the Working Group II to the Fifth Assessment Report of the

854 Intergovernmental Panel on Climate Change. (eds V.R. Barros, C.B. Field, D.J. Dokken,

855 M.D. Mastrandrea, K.J. Mach, T.E. Bilir, M. Chatterjee, K.L. Ebi, Y.O. Estrada, R.C.

856 Genova, B. Girma, E.S. Kissel, A.N. Levy, S. MacCracken, P.R. Mastrandrea \& L.L.

857

858

859

860

861 Nicholson, S.E. \& Dezfuli, A.K. (2013). The Relationship of Rainfall Variability in Western

862 Equatorial Africa to the Tropical Oceans and Atmospheric Circulation . Part I : The Boreal

863 Spring. Journal of Climate, 26.

864 Nicholson, S.E., Funk, C. \& Fink, A.H. (2018). Rainfall over the African continent from the 19th

865

866 through the 21st century. Global and Planetary Change, 165, 114-127.

867 West Africa and equatorial Africa. Journal of Climate, 16, 1013-1030.

868 NOAA. (2018). U.S. Daily Climate Normals (1981-2010). National Centers for Environmental

869 Information. URL https://data.nodc.noaa.gov/cgi-bin/iso?id=gov.noaa.ncdc:C00823

$870 \quad$ [accessed 26 November 2018]

871 Oliveira, R.S., Eller, C.B., Bittencourt, P.R. and Mulligan, M. (2014). The hydroclimatic and

872 ecophysiological basis of cloud forest distributions under current and projected climates. Annals

873 of botany, 113(6), pp.909-920.

874 Otto, F.E.L., Jones, R.G., Halladay, K. \& Allen, M.R. (2013). Attribution of changes in 
875

876

877

878

879

880

881

882

883

884

885

886

887

888

889

890

891

892

893

894

895

896

897

898

899

900

901

902

903

904

905

906

907

908

909

910

911

912

913

914

precipitation patterns in African rainforests. Philosophical transactions of the Royal Society of London. Series B, Biological sciences, 368, 20120299.

Peterson, T.C., Easterling, D.R., Karl, T.R., Groisman, P., Nicholls, N., Plummer, N., Torok, S., Auer, I., Boehm, R., Gullett, D. and Vincent, L., 1998. Homogeneity adjustments of in situ atmospheric climate data: a review. International Journal of Climatology: A Journal of the Royal Meteorological Society, 18(13), pp.1493-1517.

Philippon, N., Cornu, G., Monteil, L., Gond, V., Moron, V., Pergaud, J., Sèze, G., Bigot, S., Camberlin, P., Doumenge, C., Fayolle, A. \& Ngomanda, A. (2019). The light-deficient climates of western Central African evergreen forests. Environmental Research Letters, 14, 34007.

Preethi, B., Sabin, T.P., AdeDay of Yearin, J.A. \& Ashok, K. (2015). Impacts of the ENSO Modoki and other tropical indo-pacific climate-drivers on African rainfall. Scientific Reports, 5, 1-15.

R Core Team (2019). R: A language and environment for statistical computing. R Foundation for Statistical Computing, Vienna, Austria. URL https://www.R-project.org/.

Reich, P.B. (1995). Phenology of tropical forests: patterns, causes, and consequences. Canadian Journal of Botany, 73, 164-174.

Rohde, R., Muller, R.A., Jacobsen, R., Muller, E., Perlmutter, S., Rosenfeld, A., Wurtele, J., Groom, D. \& Wickham, C. (2013). A new estimate of the average Earth surface land temperature spanning 1753 to 2011. Geoinfor Geostat Overview 1, 7, 2.

Saji, N.H. \& Yamagata, T. (2003). Possible impacts of Indian Ocean dipole mode events on global climate. Climate Research, 25, 151-169.

Sakai, S. (2001). Phenological diversity in tropical forests. Population Ecology, 43, 77-86.

van Schaik, C.P., Terborgh, J.W. \& Wright, J.S. (1993). The phenology of tropical forests: Adaptive significance and consequences for primary consumers. Annual Review of Ecology and Systematics, 24, 353-377.

Schefuss, E., Schouten, S. \& Schneider, R.R. (2005). Climatic controls on central African hydrology during the past 20, 000 years. Nature, 437, 1003-1006.

Suggitt, A.J., Platts, P.J., Barata, I.M., Bennie, J.J., Burgess, M.D., Bystriakova, N., Duffield, S., Ewing, S.R., Gillingham, P.K., Harper, A.B., Hartley, A.J., Hemming, D.L., Maclean, I.M.D., Maltby, K., Marshall, H.H., Morecroft, M.D., Pearce-Higgins, J.W., Pearce-Kelly, P., Phillimore, A.B., Price, J.T., Pyke, A., Stewart, J.E., Warren, R. \& Hill, J.K. (2017). Conducting robust ecological analyses with climate data. Oikos, 126, 1533-1541.

Suzuki, T. (2011). Seasonal variation of the ITCZ and its characteristics over central Africa. Theoretical and Applied Climatology, 103, 39-60.

Tarik C. Gouhier, Aslak Grinsted, Viliam Simko (2019). R package biwavelet: Conduct Univariate and Bivariate Wavelet Analyses (Version 0.20.19). Available from https://github.com/tgouhier/biwavelet

Todd, M.C. \& Washington, R. (2004). Climate variability in central equatorial Africa: Influence from the Atlantic sector. Geophysical Research Letters, 31, 1-4. 
915 Torrence, C. and Compo, G.P., 1998. A practical guide to wavelet analysis. Bulletin of the

916 American Meteorological society, 79(1), pp.61-78.

917 Tutin, C.E.G. \& Fernandez, M. (1993). Relationships between minimum temperature and fruit

918 production in some tropical forest trees in Gabon. Journal of Tropical Ecology, 9, 241-248.

919 University of East Anglia Climatic Research Unit, Harris, I.C.. \& Jones, P.D. (2017). CRU

920 TS4.01: Climatic Research Unit (CRU) Time-Series (TS) version 4.01 of high-resolution

921 gridded data of month-by-month variation in climate (Jan. 1901-Dec. 2016).

922 van Rij J, Wieling M, Baayen R, van Rijn H (2017). "itsadug: Interpreting Time Series.

923 and Autocorrelated Data Using GAMMs." R package version 2.3.Washington, R., James, R.,

924 Pearce, H., Pokam, W.M. \& Moufouma-Okia, W. (2013). Congo Basin rainfall climatology:

925 can we believe the climate models? Philosophical transactions of the Royal Society of

926 London. Series B, Biological sciences, 368, 20120296.

927 Willis, K.J., Bennett, K.D., Burrough, S.L., Macias-Fauria, M. \& Tovar, C. (2013). Determining

928 the response of African biota to climate change : using the past to model the future.

929 Philosophical transactions of the royal society, 368, 20120491.

930 Wilson, A.M. \& Jetz, W. (2016). Remotely Sensed High-Resolution Global Cloud Dynamics for

931 Predicting Ecosystem and Biodiversity Distributions. PLOS Biology, 14, e1002415.

932 Wolter, K. (2018). Multivariate ENSO Index (MEI). URL

933 https://www.esrl.noaa.gov/psd/enso/mei/ [accessed 24 July 2018]

934 Wolter, K. \& Timlin, M.S. (1998). Measuring the strength of ENSO events: How does 1997/98

935 rank? Weather, 53, 315-324.

936 Wolter, K. \& Timlin, M.S. (1993). Monitoring ENSO in COADS with a seasonally adjusted

937 principal component index. Proc. of the 17th Climate Diagnostics Workshop, pp. 52-57.

938 Norman, OK, NOAA/NMC/CAC, NSSL, Oklahoma Clim. Survey, CIMMS and the School

939 of Meteor., Univ. of Oklahoma.

940 Wright, S. (1996). Phenological responses to seasonality in tropical forest plants. Tropical forest 941 plant ecophysiology, pp. 440-460. Springer, Boston, MA.

942 Wright, S.J. \& Calderón, O. (2018). Solar irradiance as the proximate cue for flowering in a 943 tropical moist forest. Biotropica, 50, 374-383.

944 Zhang, Y., Tan, Z., Song, Q., Yu, G. \& Sun, X. (2010). Respiration controls the unexpected 945 seasonal pattern of carbon flux in an Asian tropical rain forest. Atmospheric Environment, $946 \quad 44,3886-3893$.

947 Zhang Y (2013). "Likelihood-based and Bayesian Methods for Tweedie Compound Poisson 948 Linear Mixed Models.”_Statistics and Computing_, *23*, 743-757.

949 Zhou, L., Tian, Y., Myneni, R.B., Ciais, P., Saatchi, S., Liu, Y.Y., Piao, S., Chen, H., Vermote, 950 E.F., Song, C. \& Hwang, T. (2014). Widespread decline of Congo rainforest greenness in 951 the past decade. Nature, 508, 86-90. 


\section{Figure 1}

\section{Global climatic influences on western equatorial Africa}

A. The forested region of central Africa is indicated by a layer of green pixels ( $>25 \%$ tree cover in 2000 from Hansen et al. 2013 - available from http://earthenginepartners.appspot.com/science-2013-global-forest). The Northern (July) and Southern limits (January) of the Inter Tropical Convergence Zone (ITCZ) are drawn from Barlow et al. (2018). The blue zones indicate patterns in oceanic sea surface temperatures (SSTs) known to influence weather in western Central Africa: the Pacific Ocean El Niño Southern Oscillation (ENSO); North and South Tropical Atlantic SSTs (NATL and SATL) and the Indian Ocean Dipole (IOD). In conventional El Niño years the tropical Eastern Pacific is abnormally warm, in El Niño Modoki the warming occurs in the central Pacific. The IOD is the difference between SSTs of the western and eastern tropical Indian Ocean. B. Lopé National Park (our study site) is indicated by a black dot and the limits of western equatorial Africa as defined in this paper are indicated by the grey rectangle (including the humid forests of Gabon, Equatorial Guinea, Cameroon and the Republic of Congo). Also the location of the seasonal Atlantic cold tongue, a pool of cool surface water that develops in the eastern tropical Atlantic during the boreal summer (drawn from Tokinaga \& Xie 2011). The grey world map was created by Layerace at Freepik.com.

A.

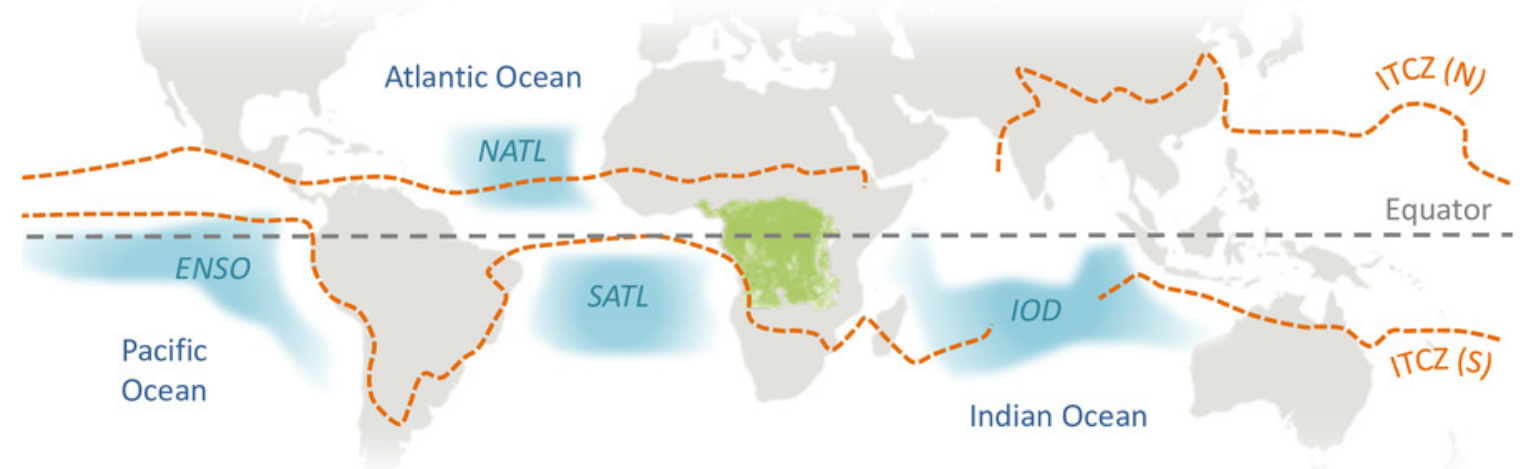

B.

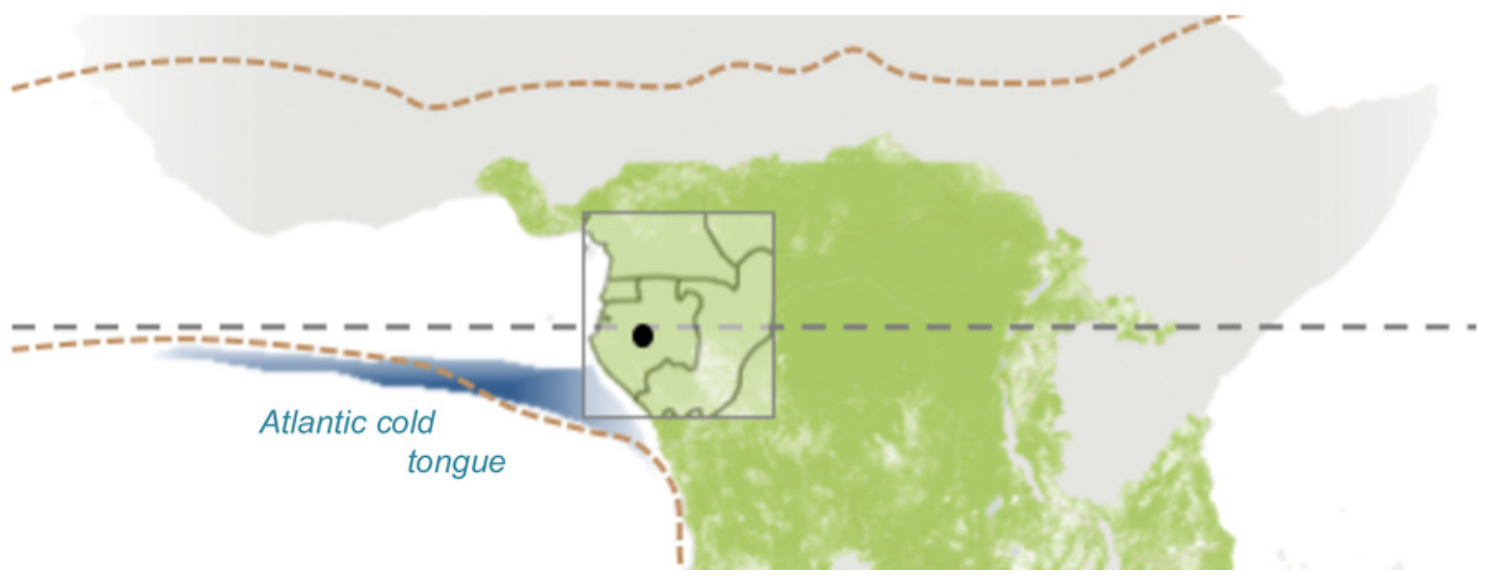




\section{Figure 2}

Seasonal weather variability at Lopé NP, Gabon.

Mean seasonality for daily rainfall (1984-2018), maximum and minimum daily temperature (1984-2017), relative humidity (2007-2015), surface solar radiation (2012-2016), wind speed (2012-2016) and aerosol optical depth at 500nm (2014-2017). The thin grey lines indicate the mean values for each day of the calendar year (DOY). The thin black lines indicate the seven-day running means of DOY and the thick black lines indicate the monthly means. Vertical dotted lines indicate the alternating rainy and dry seasons. 
A

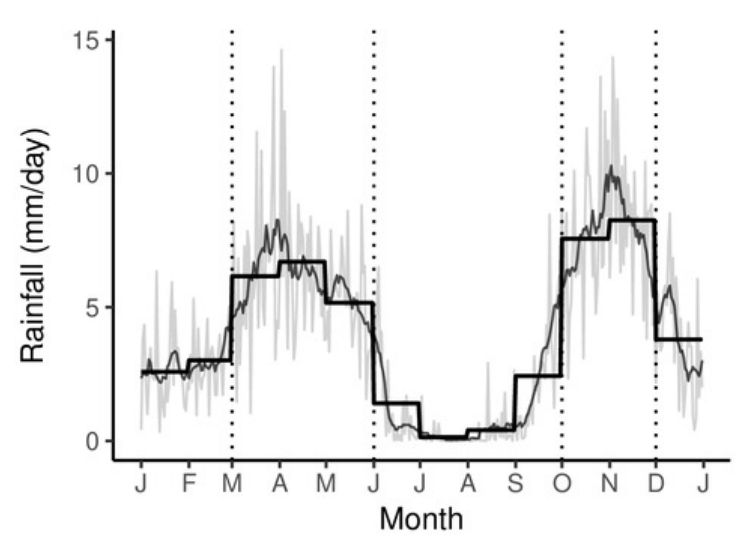

C

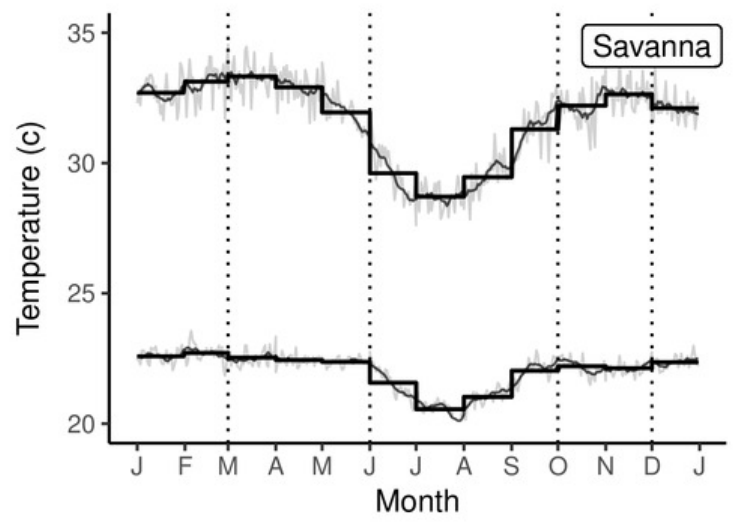

E

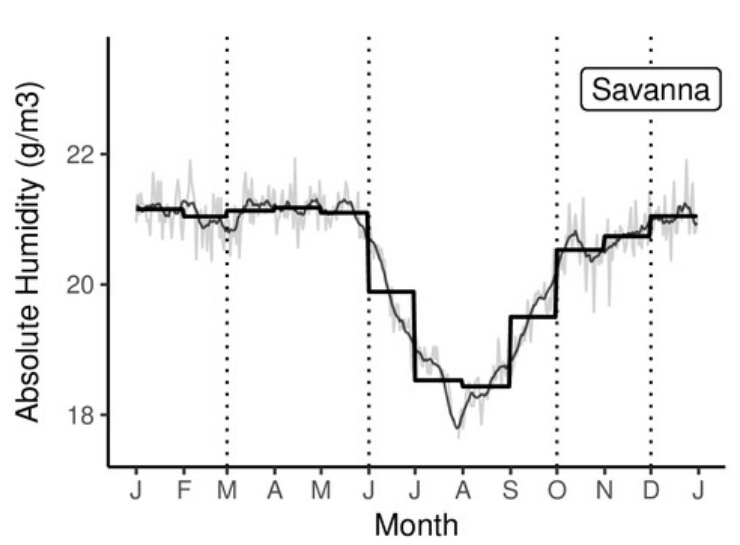

G

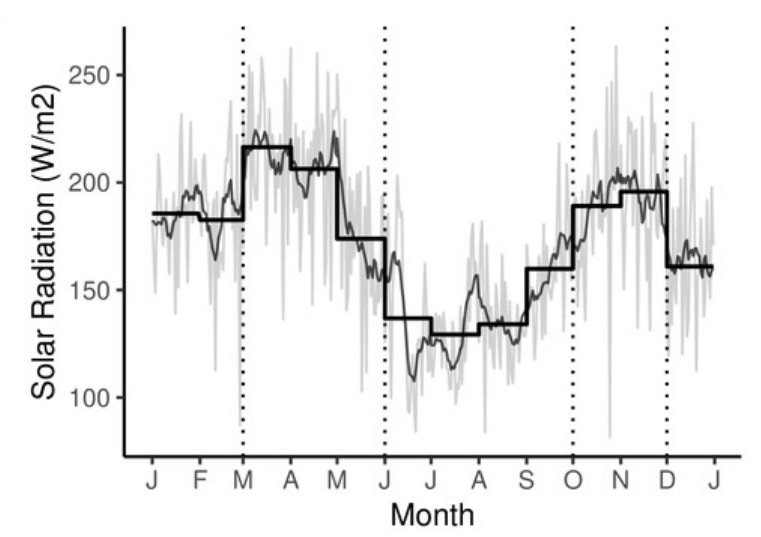

B

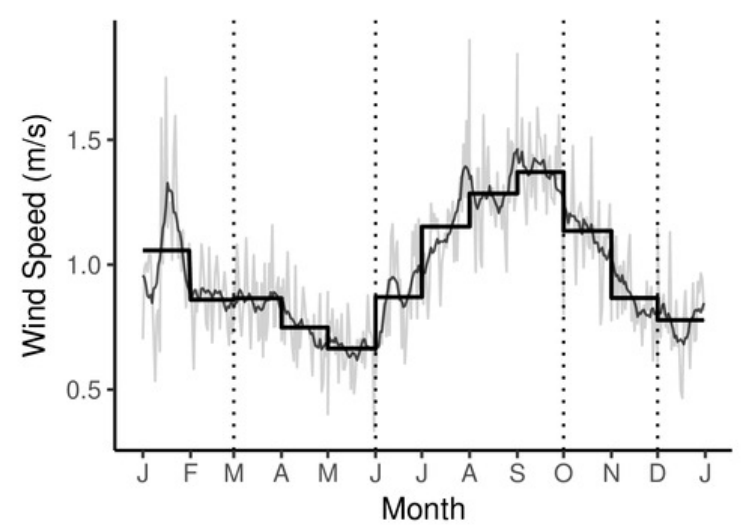

D

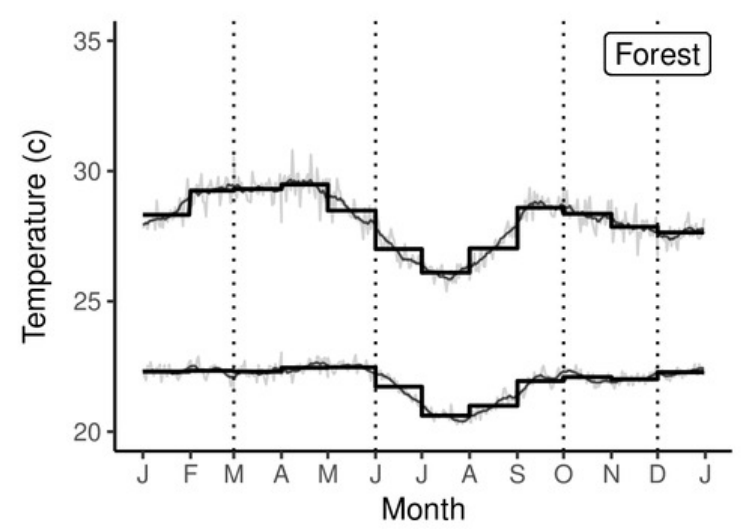

F

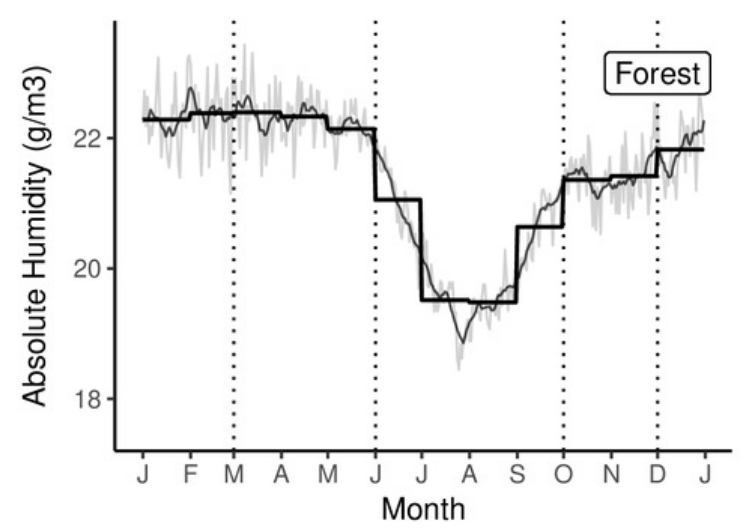

H

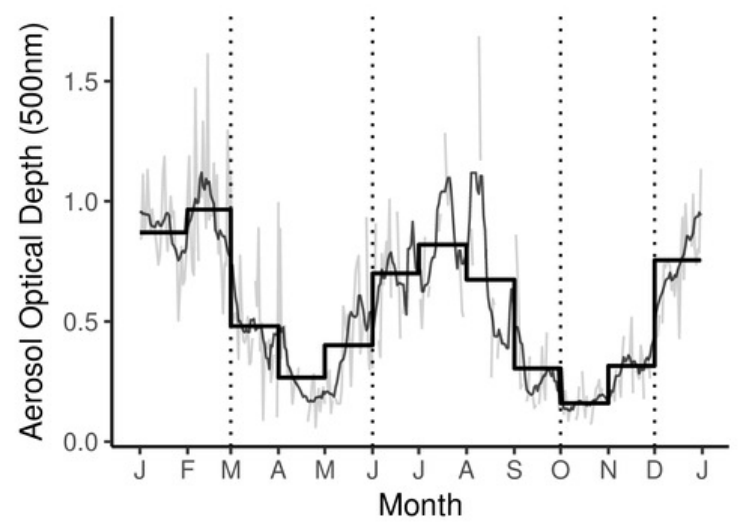




\section{Figure 3}

Inter-annual variation, long-term trends and periodicity for rainfall and temperature at Lopé NP, Gabon.

(A) The grey lines indicate inter-annual variation and the black line indicates the long-term trend for total annual rainfall (1984-2018) derived from a compound poisson generalised linear mixed model. (B) The grey dots indicate raw daily data summarised to monthly means and the black line indicates the long-term trend for minimum daily temperature (1984-2018) derived from a linear mixed model. (C, D) Wavelet transforms of the standardised monthly time-series for total monthly rainfall and mean minimum daily temperature. The faded region indicates the "cone of influence" where end effects make the data unreliable. The colour indicates the power of the cycle at each time period, red= high power and blue = low power. Bold black lines indicate cycles with significant power (Chi-sq test). (E, F) Extracted wavelet components for the biannual, annual and multi-annual (mean of 2-4 years) periods from the wavelet transforms, adjusted for edge effects. Both $\mathrm{E}$ and $\mathrm{F}$ share the same legend. 
A

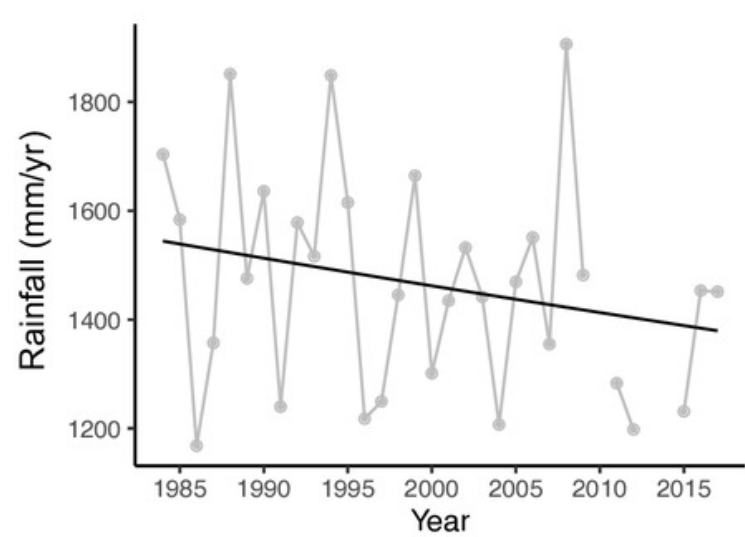

C

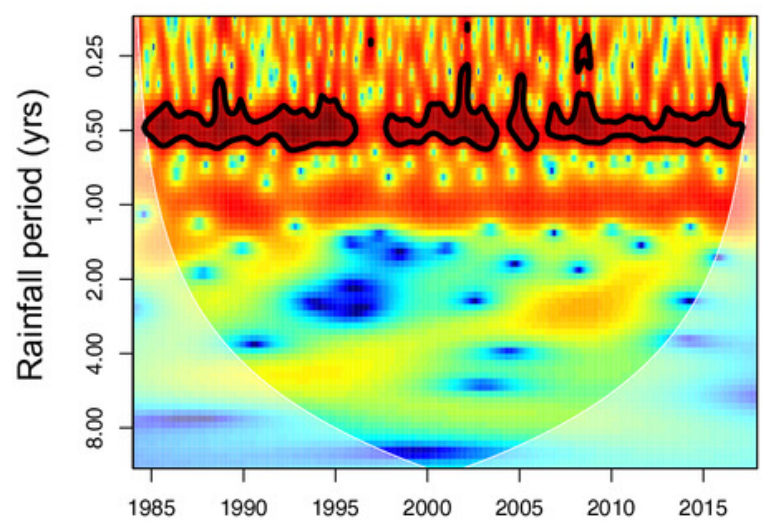

E

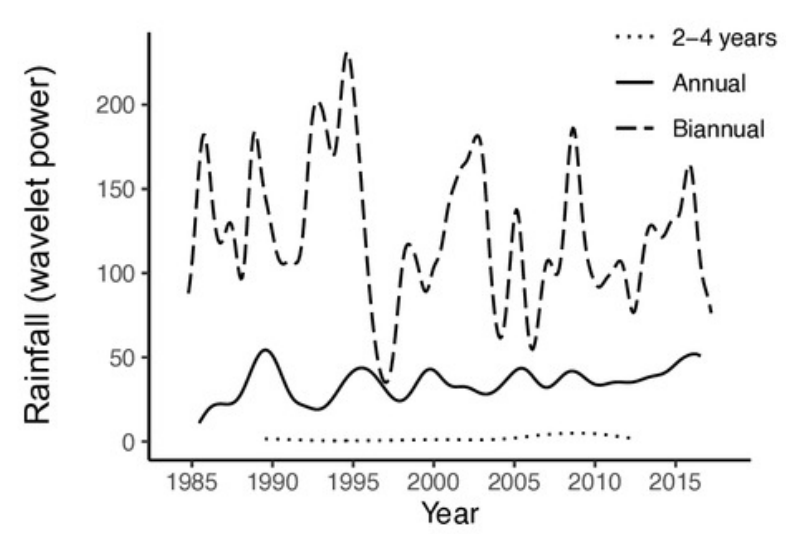

B

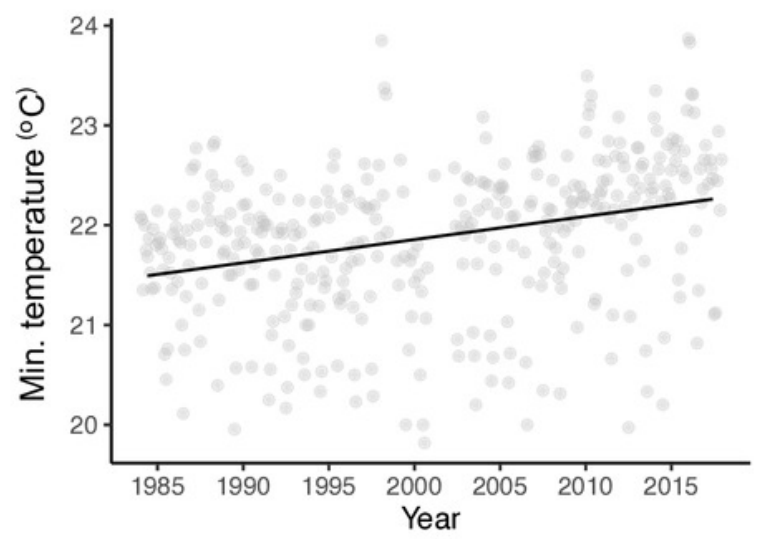

D

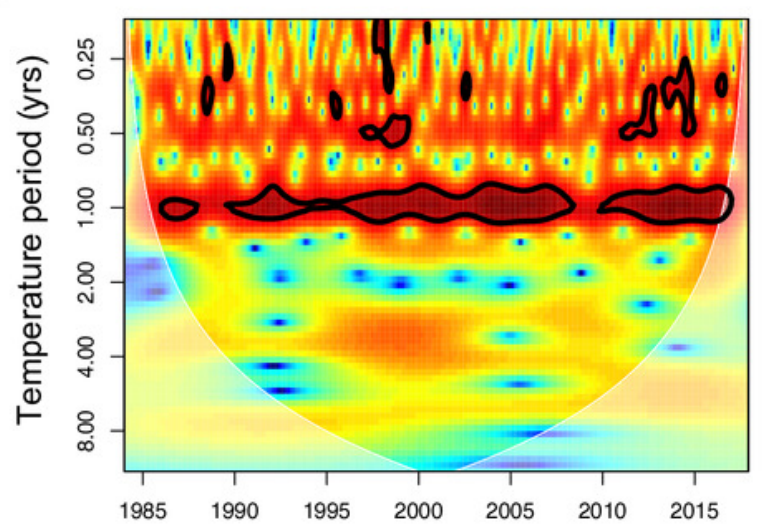

$\mathrm{F}$

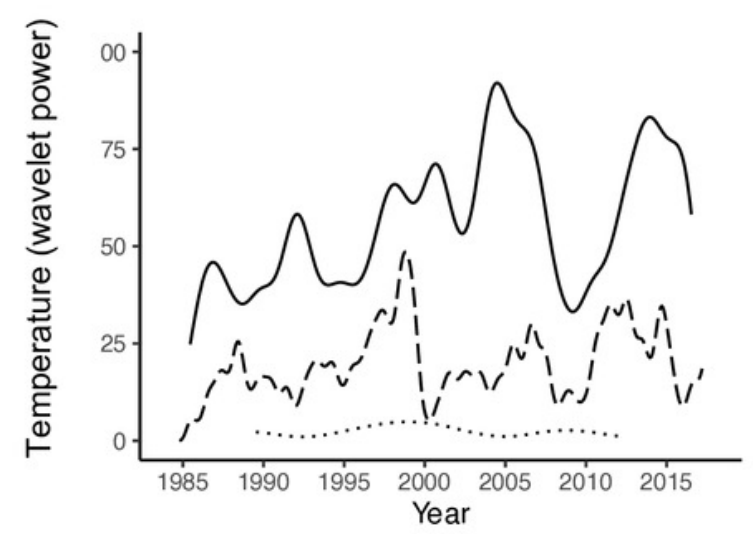




\section{Figure 4}

The influence of oceanic sea surface temperatures on weather at Lopé NP, Gabon.

Wavelet coherence plots for all eight combinations of $\mathrm{x}$ (rainfall or minimum temperature) against y $(\mathrm{MEI}=$ Multivariate ENSO Index, NATL = northern tropical Atlantic SST, SATL= southern equatorial Atlantic SST, IOD = Indian Ocean Dipole). The coloured region indicates the reliable data within the "cone of influence" away from edge effects. The colour indicates the strength of coherency between the time series at each period through time, red= high coherency and blue = low coherency. Bold black lines indicate areas with significant coherency (derived from Monte Carlo randomizations). Arrows indicate the phase relationship between the time series within areas of strong coherency. Arrows pointing to the right mean that $x$ and $y$ are in phase. Arrows pointing to the left mean that $x$ and $y$ are in anti-phase. Arrows pointing up mean that $y$ leads $x$ by $\pi / 2$. Arrows pointing down mean that $x$ leads $y$ by $\pi / 2$. 

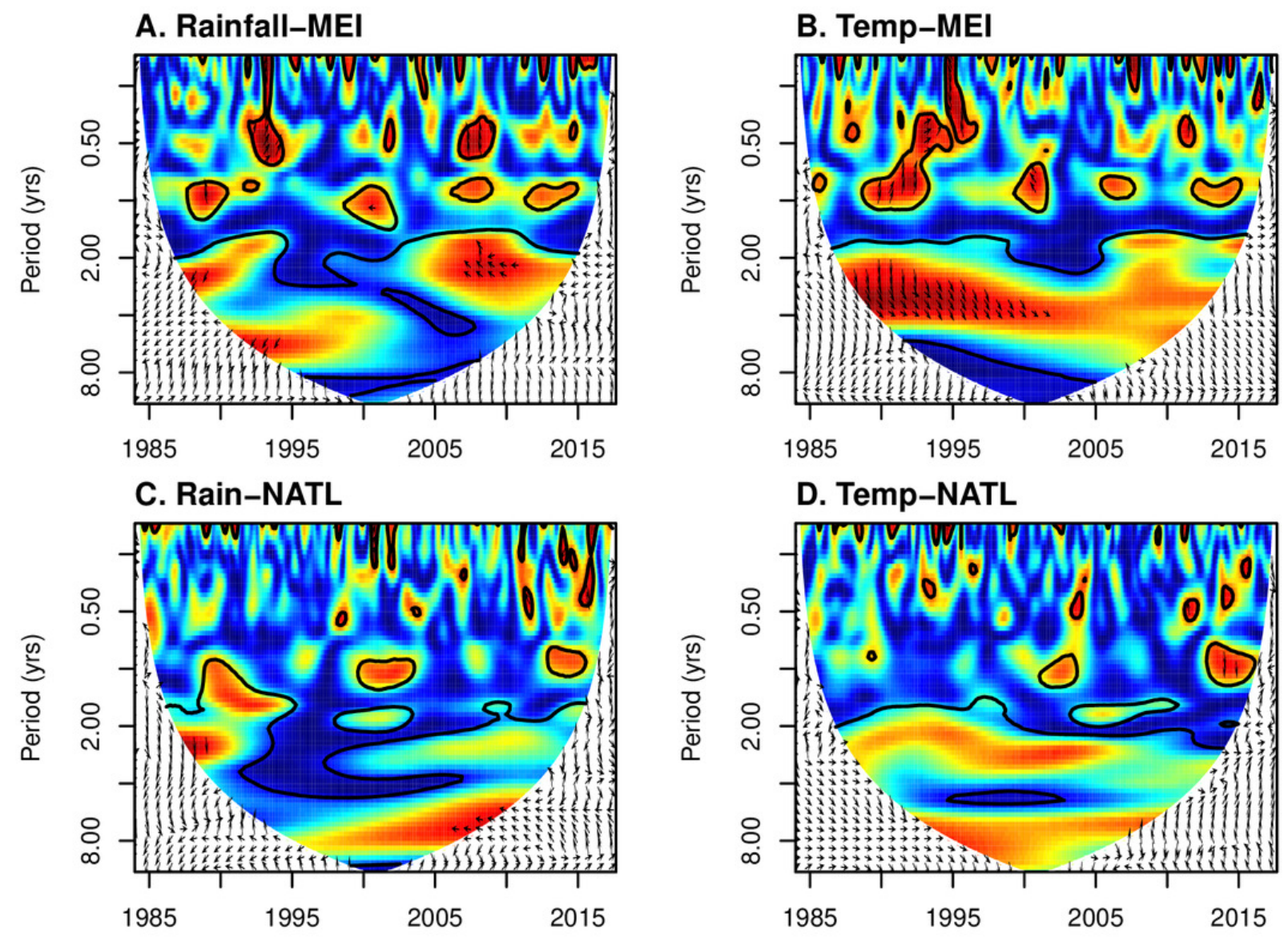

E. Rain-SATL
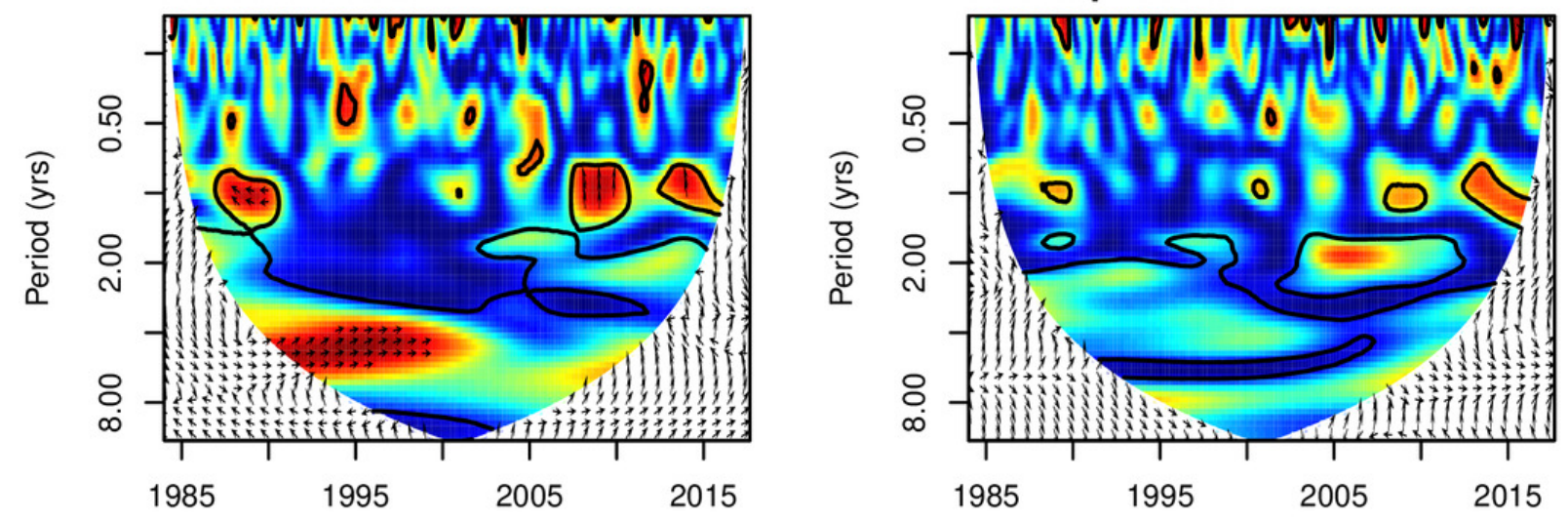

G. Rain-IOD
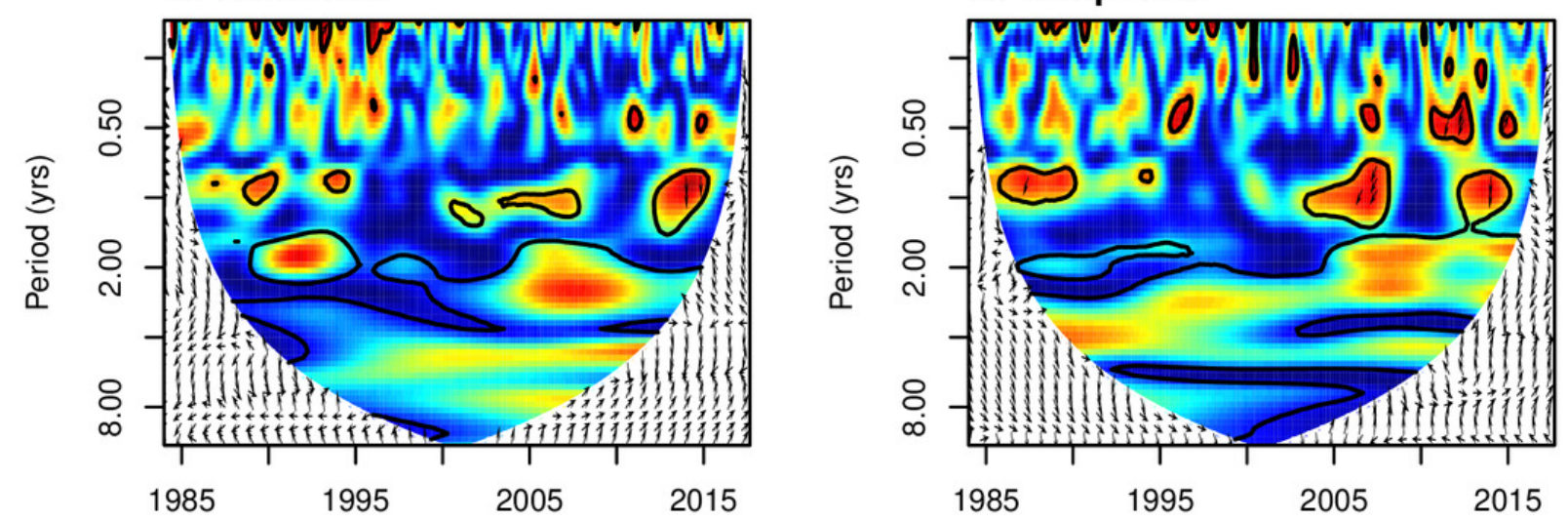

PeerJ reviewing PDF | (2019:05:37246:2:0:NEW 28 Jan 2020) 


\section{Table $\mathbf{1}$ (on next page)}

Major oceanic influences on rainfall in western equatorial Africa. 


\begin{tabular}{|c|c|c|c|}
\hline Study & Description & Ocean in & luences \\
\hline $\begin{array}{l}\text { Preethi et al } \\
2015 .\end{array}$ & $\begin{array}{l}\text { Africa-wide; } \\
\text { Satellite and } \\
\text { gridded obs.; } \\
\text { 1979-2010. }\end{array}$ & $\begin{array}{l}\text { Pacific: } \\
\text { Indian: }\end{array}$ & $\begin{array}{l}\text { Canonical El Niño reduces rainfall Jan-Sep. El } \\
\text { Niño Modoki increases rainfall Mar-May. } \\
\text { Positive relationship between SSTs and rainfall } \\
\text { Jan-Feb. No relationship between IOD and } \\
\text { rainfall. }\end{array}$ \\
\hline $\begin{array}{l}\text { Camberlin et } \\
\text { al. } 2001 \text {. }\end{array}$ & $\begin{array}{l}\text { Sub-Sahara; } \\
\text { Gridded obs.; } \\
\text { 1951-1997. }\end{array}$ & $\begin{array}{l}\text { Pacific: } \\
\text { Atlantic: }\end{array}$ & $\begin{array}{l}\text { El Niño negatively influences rainfall Apr-Jun. } \\
\text { South Atlantic SSTs positively influence rainfall } \\
\text { Apr-Sep. }\end{array}$ \\
\hline $\begin{array}{l}\text { Balas et al. } \\
2007 .\end{array}$ & $\begin{array}{l}\text { WEA; } \\
\text { Precipitation } \\
\text { gauge dataset; } \\
1950-1998 .\end{array}$ & $\begin{array}{l}\text { Pacific: } \\
\text { Indian: }\end{array}$ & $\begin{array}{l}\text { El Niño negatively influences rainfall. } \\
\text { Weak positive relationship between SSTs and } \\
\text { rainfall in all seasons except Mar-May when it is } \\
\text { reversed. } \\
\text { Positive correlation between south Atlantic SSTs } \\
\text { and rainfall Jun-Nov, negative influence Dec- } \\
\text { Feb. Benguela coast influences rain Mar-May. }\end{array}$ \\
\hline $\begin{array}{l}\text { Todd \& } \\
\text { Washington } \\
2004 .\end{array}$ & $\begin{array}{l}\text { CEA and WEA; } \\
\text { Gridded obs. and } \\
\text { discharge data } \\
\text { Feb-Apr; 1901- } \\
1998 .\end{array}$ & $\begin{array}{l}\text { Pacific: } \\
\text { Atlantic: }\end{array}$ & $\begin{array}{l}\text { El Niño has weak negative influence on rainfall } \\
\text { Feb-Apr. } \\
\text { North Atlantic Oscillation negatively influences } \\
\text { rainfall Feb-Apr. }\end{array}$ \\
\hline $\begin{array}{l}\text { Otto et al. } \\
2013 \text {. }\end{array}$ & $\begin{array}{l}\text { CEA and WEA; } \\
\text { Simulated data. } \\
\text { Dry seasons only. }\end{array}$ & $\begin{array}{l}\text { Pacific: } \\
\text { Indian: } \\
\text { Atlantic: }\end{array}$ & $\begin{array}{l}\text { ENSO influences rainfall in dry seasons. } \\
\text { IOD negatively influences rainfall in dry seasons. } \\
\text { Warm tropical Atlantic SSTs enhance rain in dry } \\
\text { seasons. }\end{array}$ \\
\hline $\begin{array}{l}\text { Nicholson \& } \\
\text { Dezfuli 2013; } \\
\text { Dezfuli \& } \\
\text { Nicholson } \\
2013 \text {. }\end{array}$ & $\begin{array}{l}\text { WEA. } \\
\text { Regionalised obs. } \\
\text { Rainy seasons } \\
\text { only. }\end{array}$ & $\begin{array}{l}\text { Pacific: } \\
\text { Indian: } \\
\text { Atlantic: }\end{array}$ & $\begin{array}{l}\text { El Niño reduces rainfall in rainy seasons. } \\
\text { Positive IOD modes associated with reduced } \\
\text { rainfall in rainy seasons. } \\
\text { Warm tropical Atlantic SSTs enhance rainfall in } \\
\text { rainy seasons. Strong correlation with Benguela } \\
\text { coast from Oct-Dec }\end{array}$ \\
\hline
\end{tabular}

$\mathrm{CEA}=$ central equatorial Africa, WEA $=$ western equatorial Africa, SST $=$ sea surface temperatures, ENSO = El Niño Southern Oscillation, IOD = Indian Ocean Dipole. 
Table 2 (on next page)

Weather station instrument record at Lopé NP, Gabon, 1984 - 2018. 


\begin{tabular}{|c|c|c|c|c|}
\hline Instrument & Time period & Location & Data & Missing periods \\
\hline Manual rain gauge & 1984 - present & Savanna & Total daily rainfall. & $\begin{array}{l}\text { Sep-2010 to Dec } \\
\text { 2010;2013; Odd } \\
\text { days. }\end{array}$ \\
\hline $\begin{array}{l}\text { Manual Max/Min } \\
\text { thermometer }\end{array}$ & $\begin{array}{l}1984 \text { - 2002; } \\
2006-2007\end{array}$ & Forest & $\begin{array}{l}\text { Max. / Min. temp. } \\
\text { since last reset. }\end{array}$ & $\begin{array}{l}\text { Jul-1998 to Jan- } \\
\text { 1999; Mar-2001 to } \\
\text { Aug-2001; } \\
\text { Intermittent } \\
\text { throughout. }\end{array}$ \\
\hline Wet/dry bulb & $1984-2002$ & Forest & Relative humidity. & $\begin{array}{l}\text { Intermittent } \\
\text { throughout. }\end{array}$ \\
\hline $\begin{array}{l}\text { HOBO Data Logger } \\
(\text { ONSET) }\end{array}$ & $2002-2006$ & $\begin{array}{l}\text { Forest }+ \\
\text { Savanna }\end{array}$ & $\begin{array}{l}\text { Temperature } \\
\text { Relative humidity. }\end{array}$ & Jun-2003. \\
\hline $\begin{array}{l}\text { Digital Max/Min } \\
\text { thermometer (Taylor } \\
1441 \text { ) }\end{array}$ & $2006-2008$ & Savanna & $\begin{array}{l}\text { Max. / Min. daily } \\
\text { temp. }\end{array}$ & Odd days. \\
\hline $\begin{array}{l}\text { TinyTag Plus } 2 \text { Data } \\
\text { Logger (Gemini) }\end{array}$ & 2007 - present & $\begin{array}{l}\text { Forest }+ \\
\text { Savanna }\end{array}$ & $\begin{array}{l}\text { Temperature; Relative } \\
\text { humidity. }\end{array}$ & $\begin{array}{l}\text { Jun-2015 to Jun- } \\
2016 \text { (Forest); } \\
\text { Intermittent } \\
\text { through } 2017 .\end{array}$ \\
\hline $\begin{array}{l}\text { Vantage Pro2 Weather } \\
\text { Station (Davis) }\end{array}$ & $2012-2014$ & Savanna & $\begin{array}{l}\text { Rainfall; Temperature; } \\
\text { Relative humidity; } \\
\text { Pressure; Wind speed; } \\
\text { Wind direction; UV } \\
\text { index; Solar radiation. }\end{array}$ & $\begin{array}{l}\text { Nov-2013; Feb- } \\
2014 \text { to Jul-2014. }\end{array}$ \\
\hline $\begin{array}{l}\text { Minimet Weather } \\
\text { Station (SKYE) }\end{array}$ & $2013-2016$ & Savanna & $\begin{array}{l}\text { Temperature; Relative } \\
\text { humidity; Wind speed; } \\
\text { Wind direction; Solar } \\
\text { radiation. }\end{array}$ & $\begin{array}{l}\text { Jan-2014 to Nov- } \\
\text { 2014; Intermittent } \\
\text { throughout. }\end{array}$ \\
\hline $\begin{array}{l}\text { Sun Photometer (NASA } \\
\text { Aeronet) }\end{array}$ & 2014 - present & Savanna & Aerosol optical depth. & $\begin{array}{l}\text { Intermittent } \\
\text { throughout. }\end{array}$ \\
\hline
\end{tabular}




\section{Table 3 (on next page)}

Model comparisons to test for long-term trends in rainfall and minimum temperature at Lopé NP, Gabon (1984-2018).

We used a compound poisson generalised linear mixed model for daily rainfall and a linear mixed model for minimum daily temperature. Day of Year and was included as a random intercept in both models 
1

\begin{tabular}{llllll}
\hline Response & Model & Predictors & DF & AIC & Delta AIC \\
\hline Rainfall & Long-term change & Year & 4 & 40839.6 & 0.0 \\
& No long-term change & Intercept only & 3 & 40842.3 & 2.7 \\
\cline { 2 - 6 } & Long-term change & Year & 4 & 22909.5 & 0.0 \\
\cline { 2 - 5 } & Nomperature long-term change & Intercept only & 3 & 23494.0 & 584.5
\end{tabular}

$3 \quad \mathrm{AIC}=$ Akaike Information Criterion, $\mathrm{DF}=$ Degrees of Freedom. 


\section{Table 4 (on next page)}

Model comparisons to test for long-term trends in rainfall and minimum temperature varying by season at Lopé NP, Gabon (1984-2018).

We used a compound poisson generalised linear mixed model for daily rainfall and a linear mixed model for minimum daily temperature. Day of Year and was included as a random intercept in both models 
1

\begin{tabular}{lllcrc}
\hline Response & Model & Predictors & DF & AIC & Delta AIC \\
\hline Rainfall & Long-term change by season & Year* Season & 10 & 40506.2 & 0.0 \\
& Long-term change not by season & Year + Season & 7 & 40519.5 & 13.3 \\
& & & & & \\
\hline Temperature & Long-term change by season & Year * Season & 10 & 22572.8 & 0.0 \\
& & & & & \\
\cline { 2 - 6 } & Long-term change not by season & Year + Season & 7 & 22582.4 & 9.6
\end{tabular}

2 AIC = Akaike Information Criterion, DF = Degrees of Freedom.

3

S 


\section{Table 5 (on next page)}

Outputs from the best models for long-term trends in rainfall and minimum daily temperature varying by season at Lopé NP, Gabon (1984-2018).

The estimates derive from a compound poisson generalised linear mixed model for daily rainfall and a linear mixed model for minimum daily temperature. Day of Year was included as a random intercept in both models. 
1

\begin{tabular}{|c|c|c|c|c|c|c|}
\hline Response & Predictor & Estimate & SE & $\mathbf{T}$ & Lower 95\% CI & Upper $95 \%$ CI \\
\hline \multirow[t]{8}{*}{ Rainfall } & DJF & 0.99 & 0.09 & 10.45 & 0.81 & 1.17 \\
\hline & JJAS & -0.82 & 0.09 & -8.97 & -1.00 & -0.64 \\
\hline & MAM & 1.67 & 0.09 & 18.32 & 1.49 & 1.85 \\
\hline & $\mathrm{ON}$ & 1.93 & 0.11 & 17.42 & 1.71 & 2.15 \\
\hline & Year: DJF & 0.03 & 0.05 & 0.62 & -0.07 & 0.13 \\
\hline & Year: JJAS & -0.28 & 0.06 & -5.08 & -0.40 & -0.16 \\
\hline & Year: MAM & -0.06 & 0.04 & -1.38 & -0.14 & 0.02 \\
\hline & Year: ON & 0.00 & 0.05 & -0.06 & -0.10 & 0.10 \\
\hline \multirow[t]{8}{*}{ Temperature } & $\mathrm{DJF}$ & 22.30 & 0.04 & 534.23 & 22.22 & 22.38 \\
\hline & JJAS & 21.22 & 0.04 & 595.76 & 21.14 & 21.30 \\
\hline & MAM & 22.33 & 0.04 & 542.42 & 22.25 & 22.41 \\
\hline & $\mathrm{ON}$ & 21.97 & 0.05 & 433.78 & 21.87 & 22.07 \\
\hline & Year: DJF & 0.30 & 0.02 & 15.13 & 0.26 & 0.34 \\
\hline & Year: JJAS & 0.17 & 0.02 & 10.42 & 0.13 & 0.21 \\
\hline & Year: MAM & 0.25 & 0.02 & 12.92 & 0.21 & 0.29 \\
\hline & Year: ON & 0.30 & 0.02 & 12.33 & 0.26 & 0.34 \\
\hline
\end{tabular}

$2 \mathrm{SE}=$ Standard Error, $\mathrm{T}=\mathrm{T}$ value, $\mathrm{Cl}=$ Confidence Interval 